\title{
Opportunities and occupations in animal and veterinary sciences based on the current careers of West Virginia University alumni
}

Stacey Michelle Hawkins

West Virginia University

Follow this and additional works at: https://researchrepository.wvu.edu/etd

\section{Recommended Citation}

Hawkins, Stacey Michelle, "Opportunities and occupations in animal and veterinary sciences based on the current careers of West Virginia University alumni" (2002). Graduate Theses, Dissertations, and Problem Reports. 1552.

https://researchrepository.wvu.edu/etd/1552

This Thesis is protected by copyright and/or related rights. It has been brought to you by the The Research Repository @ WVU with permission from the rights-holder(s). You are free to use this Thesis in any way that is permitted by the copyright and related rights legislation that applies to your use. For other uses you must obtain permission from the rights-holder(s) directly, unless additional rights are indicated by a Creative Commons license in the record and/ or on the work itself. This Thesis has been accepted for inclusion in WVU Graduate Theses, Dissertations, and Problem Reports collection by an authorized administrator of The Research Repository @ WVU. For more information, please contact researchrepository@mail.wvu.edu. 


\title{
Opportunities and Occupations in Animal and Veterinary Sciences Based on the Current Careers of West Virginia University Alumni
}

\author{
Stacey M. Hawkins
}

\author{
Thesis submitted to the \\ Davis College of Agriculture, Forestry, and Consumer Sciences \\ at West Virginia University \\ in partial fulfillment of the requirements \\ for the degree of
}

\author{
Master of Science \\ in \\ Agricultural and Environmental Education
}

\author{
Harry N. Boone, Ph. D., Chair \\ Layle D. Lawrence, Ph. D. \\ Stacy A. Gartin, Ph. D. \\ Kerry S. Odell, Ph. D. \\ Robert A. Dailey, Ph. D.
}

\section{Morgantown, West Virginia \\ 2002}

Keywords: Animal Science, Careers, Occupations, Alumni, and College Graduates 


\title{
ABSTRACT \\ Opportunities and Occupations in Animal and Veterinary Sciences Based on the Current Careers of West Virginia University Alumni
}

\begin{abstract}
Stacey M. Hawkins
The primary purpose of this study was to examine the career opportunities for graduates completing a Bachelor of Science degree in Animal and Veterinary Sciences at West Virginia University as measured by the first and current careers of alumni. The target population consisted of all alumni that graduated between the years 1991 and 2001 . Over $61.6 \%$ of the West Virginia University Animal and Veterinary Science graduates were satisfied with both their first career selection as well as their current career. After graduating with a Bachelor of Science degree two-thirds of the graduates decided to pursue a post-graduate degree. Professional careers, doctors, veterinarian, or other medical health care careers, accounted for $36.1 \%$ of the current careers for the respondents. Respondents first (70.6\%) and current careers $(79.2 \%)$ were in the field of their choice. The most important attributes in a graduate's first career were the ability to work with people, ability to gain and use knowledge, and verbal communication skills.
\end{abstract}




\section{ACKNOWLEDGEMENTS}

The writer would like to thank all the graduates who took the time to answer the survey. I hope that this study will benefit students who enroll in the Davis College of Agriculture, Forestry and Consumer Sciences and Animal and Veterinary Sciences in the future. To my committee members Dr. Dailey, Dr. Lawrence, and Dr. Gartin, thank you for taking time out of your busy schedules to assist me in finishing my degree. To Dr. Odell, thank you for helping get my thesis started and organized. Dr. Boone thank you so much for always lending me advice and leading me in the right direction, I could not have done this without you.

Thanks to my parents, Terry and Sheila, for helping me through the first years of college. Thanks to my sisters, Kim, Shelly and Terra, for always being there to listen and lend support. Thank you Kim, Terra, and Becky for helping me stuff envelopes. I love you all. 


\section{TABLE OF CONTENTS}

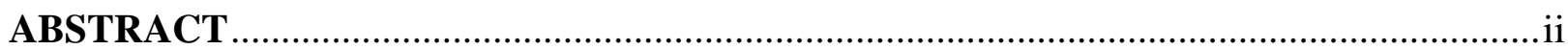

ACKNOWLEDGEMENTS …......................................................................................

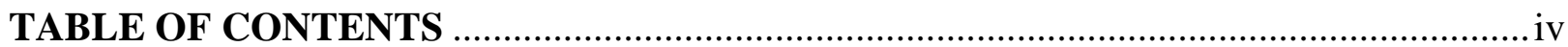

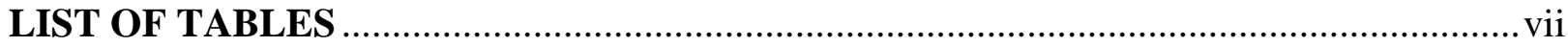

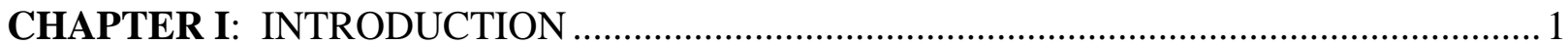

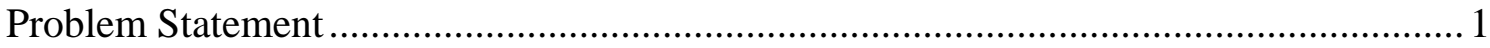

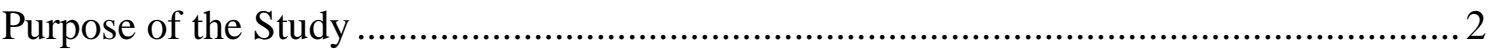

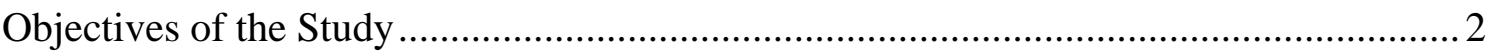

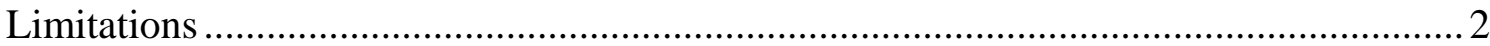

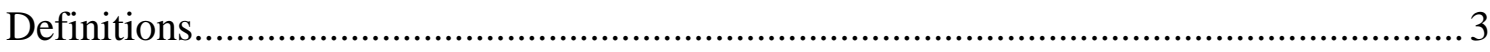

CHAPTER II: REVIEW OF LITERATURE ………………........................................

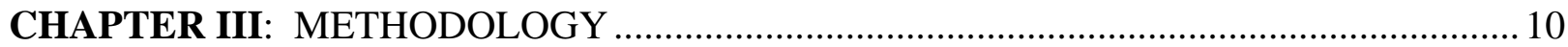

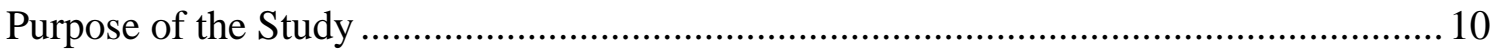

Specific Objectives ................................................................................................... 10

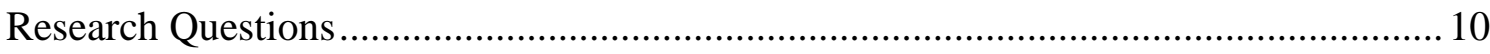

Research Design...................................................................................................... 11

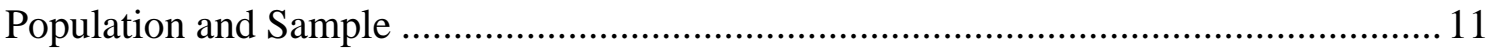

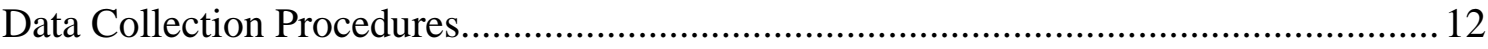

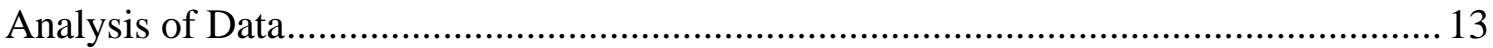

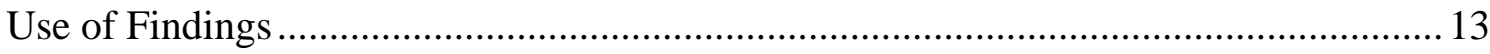

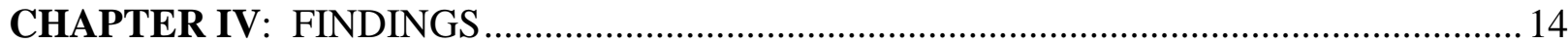




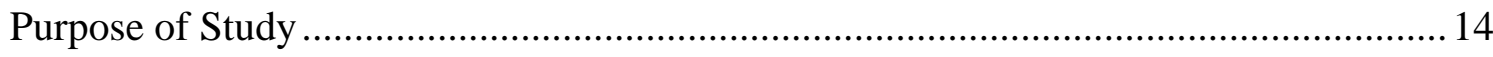

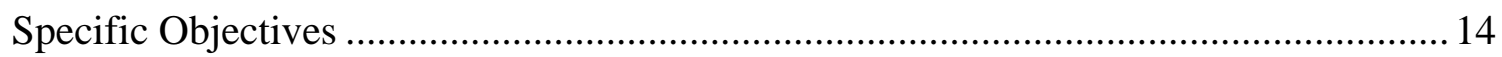

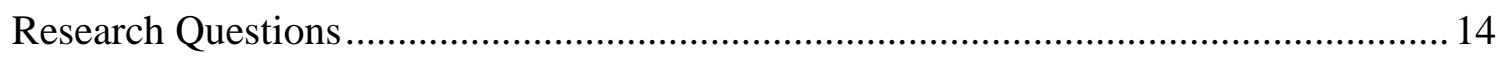

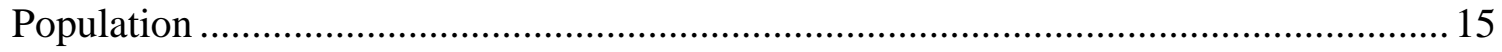

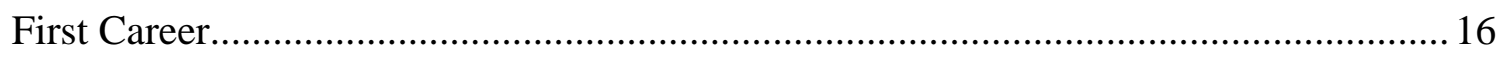

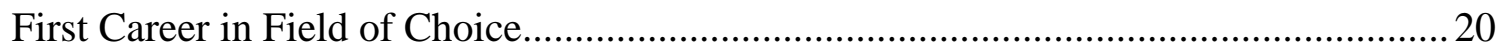

Time to Secure and Length of First Career.......................................................... 20

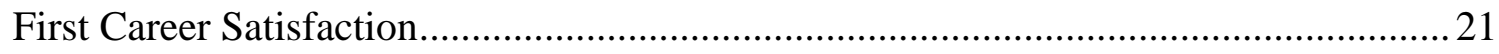

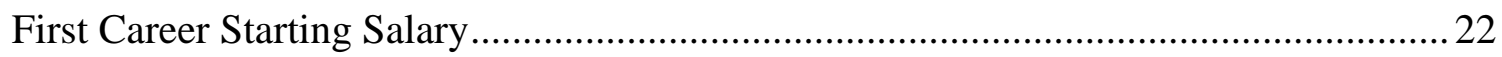

Importance of Specific Attributes in First Career .................................................. 24

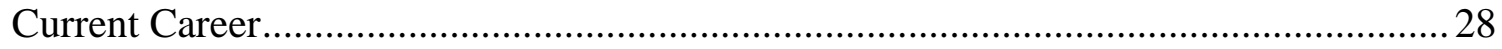

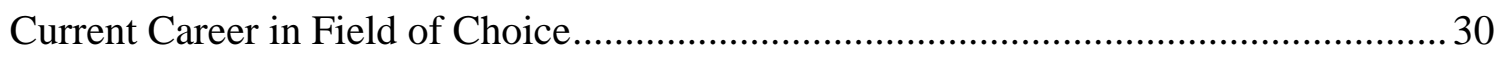

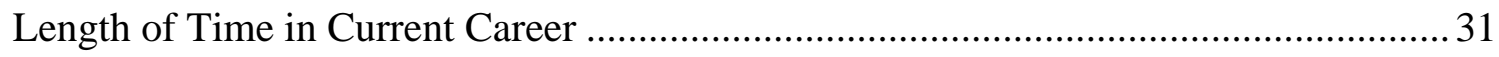

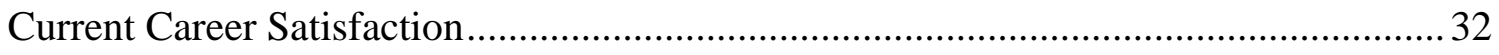

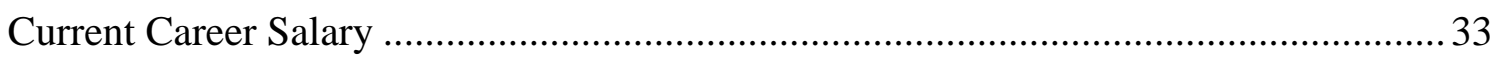

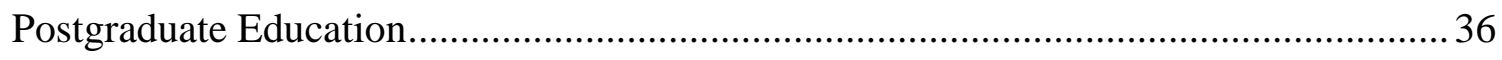

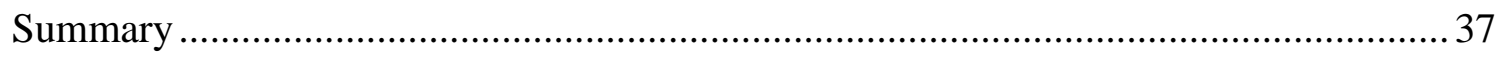

CHAPTER V: SUMMARY, CONCLUSIONS, AND RECOMMENDATIONS ................... 40

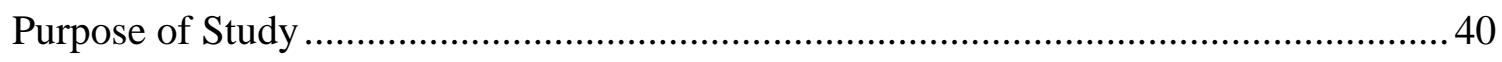

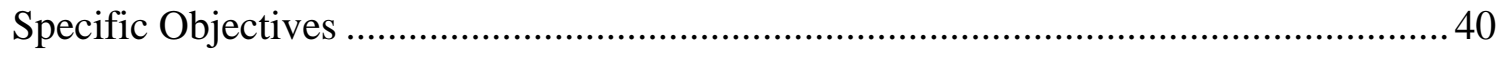

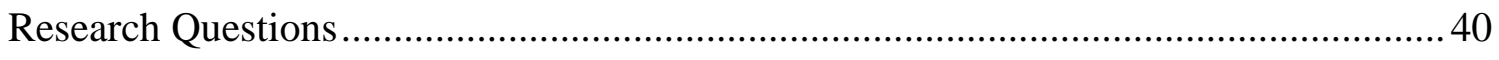

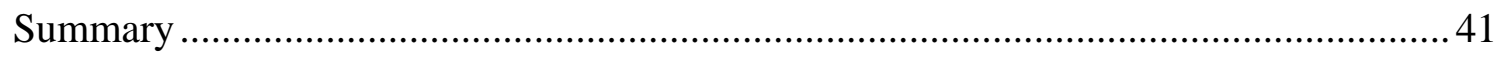

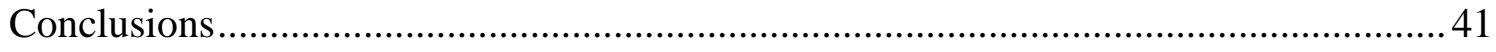




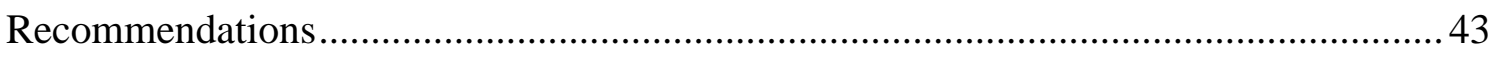

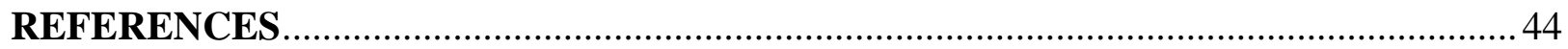

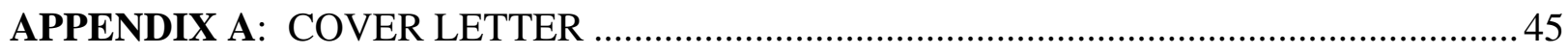

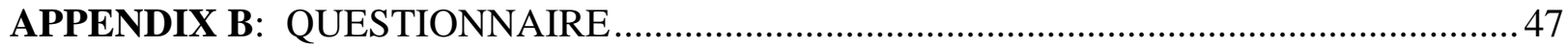

APPENDIX C: SECOND COVER LETTER ...........................................................5

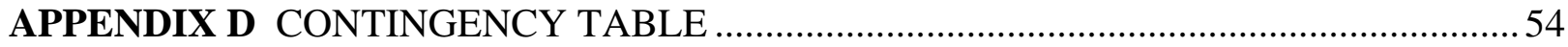

VITA 


\section{LIST OF TABLES}

Table 1: Gender and Year Graduated of West Virginia University's Animal and

Veterinary Sciences Graduates - 1991-2001

Table 2: First Career of West Virginia University's Animal and Veterinary Sciences

Graduates - 1991-2001

Table 3: Was the First Career of West Virginia University's Animal and Veterinary

Sciences Graduates - 1991-2001 in their Field of Choice?

Table 4: Time to Secure and Length of First Career for West Virginia University's

Animal and Veterinary Sciences Graduates - 1991-2001

Table 5: First Career Satisfaction of West Virginia University's Animal and

Veterinary Sciences Graduates - 1991-2001

Table 6: First Career Starting Salary of West Virginia University's Animal and

Veterinary Sciences Graduates - 1991-2001 ( $n=118)$

Table 7: Rating of the Importance of Specific Attributes in the First Career of of

West Virginia University's Animal and Veterinary Sciences Graduates - 1991-2001

Table 8: Current Career for West Virginia University's Animal and Veterinary

Sciences Graduates - 1991-2001 ( $\mathrm{n}=132)$

Table 9: Was the Current Career of West Virginia University's Animal and

Veterinary Sciences Graduates - 1991-2001 in their Field of Choice? (n=120) 31

Table 10: Years in Current Career for West Virginia University's Animal and

Veterinary Sciences Graduates - 1991-2001

Table 11: Current Career Satisfaction for West Virginia University's Animal and

Veterinary Sciences Graduates - 1991-2001 (n=118) 
Table 12: Current Career - Salary for West Virginia University's Animal and

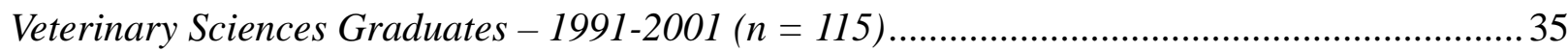

Table 13: Did West Virginia University's Animal and Veterinary Sciences

Graduates - 1991-2001 earn a Post-Graduate Degree or take Graduate Level

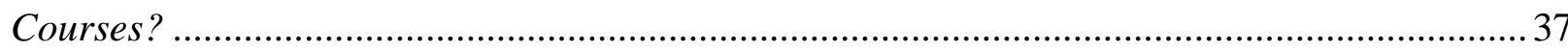

Table 14: What Type of Post-Graduate Degree did West Virginia University's

Animal and Veterinary Sciences Graduates - 1991-2001 earn? ................................................38 


\section{CHAPTER I}

\section{INTRODUCTION}

Students earning a Bachelor of Science degree in Animal and Veterinary Sciences at West Virginia University have a wide variety of career opportunities. According to the American Society of Animal Science (ASAS) web site for 2002, there are over 500 jobs for which a student holding this degree may be qualified. These areas of animal science include livestock production, veterinary medicine, meat or dairy foods, livestock promotion and marketing, sales, management, financial institutions, service organizations, livestock feed, and technology development and application. Career opportunities depend on the specific program of study chosen by the student. Some of the career opportunities available in animal agriculture deal with the business, government, industry, research, and educational aspects of animal science. Students enrolled in an Animal and Veterinary Sciences curriculum receive primary education in the natural and biological sciences. The Division of Animal and Veterinary Sciences requires the student to complete 40-48 hours in the area of natural sciences (courses in biology, chemistry, physics, and calculus are required) at West Virginia University. The ASAS (2001) also noted that for students to have a more rounded education they should have courses related to communication, economics, computer technology, and business.

\section{$\underline{\text { Problem Statement }}$}

A primary reason most students enter the Animal and Veterinary Sciences program at West Virginia University is to prepare for post-graduate education at a school of veterinary medicine. What career options are available for students that do not gain admission or who choose not to go on to a veterinary school? The employment opportunities after graduating with a Bachelor of Science in Animal and Veterinary Sciences have received very little study. The 
only information available dealt with teaching programs on a college level, high school level, or adult education levels (Meyer, 1990).

Should the Animal and Veterinary Sciences curriculum be changed to reflect the career paths chosen by recent graduates of the program? Some post-graduate careers may require additional skills; therefore additional courses may need to be incorporated into the undergraduate curriculum. Other careers may require additional courses of instruction in specific areas of animal management. This information will be useful for incoming students as well as current students of the animal science curriculum. The types of occupations that alumni of the Animal and Veterinary Sciences program hold may also have an influence on the type of elective courses an animal science major completes. It may be important to the animal science program that the students know the career choices and opportunities presently available with the degree they are attaining.

\section{Purpose of the Study}

The primary purpose of this study was to examine the career opportunities for graduates completing a Bachelor of Science degree in Animal and Veterinary Sciences at West Virginia University as measured by the first and current occupations of alumni.

Objectives of the Study

The objectives of the study were to: (1) identify the type and selected factors associated with the first career/occupational status of recent graduates and to (2) identify the type and selected factors associated with the current career/occupational status of recent graduates. $\underline{\text { Limitations }}$

The study was limited to graduates of the Division of Animal and Veterinary Sciences who completed a Bachelor of Science degree in Animal and Veterinary Sciences at West 
Virginia University between 1991 and 2001. Therefore, the findings could only be generalized to those participating in the study. The findings of this study also relied on the accuracy and truthfulness of the students' responses to the survey questions.

\section{$\underline{\text { Definitions }}$}

Animal science - The science and business of producing livestock species. It also deals with production of food animals, processing and consumption of meat and dairy products, maintenance of animal health and well-being, and the use of companion animals for leisure or recreational purposes.

Bachelor of Science in Animal and Veterinary Sciences - A pre-professional program at WVU which provides one with the opportunity to acquire the necessary background in agricultural biochemistry, chemistry, mathematics, physics, and modern concepts of biology in preparation for professional schools of veterinary medicine, human medicine, dentistry, optometry, pharmacy, or graduate study in fields such as agricultural biochemistry, animal breeding, animal physiology, and nutrition.

West Virginia University - West Virginia University, founded in 1867, is located in Morgantown, West Virginia, a city of 27,000 residents near West Virginia's northern border. It is one of only 46 public universities that serve their state as research and land grant institutions.

Animal Science Division - In the Division of Animal and Veterinary Sciences at WVU, students take courses such as agricultural biochemistry, animal production, breeding and genetics, food science, nutrition, pathology, and physiology. To assist students in preparing for the various careers in animal agriculture, the Division requires students to enroll in supporting courses in other divisions of the Davis College of Agriculture, Forestry and Consumer Sciences and in other colleges. Concentration is in biological and 
natural sciences and mathematics. Included in the requirements for the Bachelor of Science degrees are 40 credit hours in the natural sciences, a minimum of two courses each in biology, chemistry, physics, and mathematics, and 24 credit hours in agriculture. Occupation - An activity engaged in especially as a means of passing time; an activity which occupies or engages the time and attention; the principal business of one's life; vocation; employment.

Career - A particular occupation for which you are trained or the general progression of your working or professional life, a chosen pursuit.

$J o b$ - A regular activity performed in exchange for payment, position in which one is employed. 


\section{CHAPTER II}

\section{REVIEW OF LITERATURE}

United States colleges and universities awarded nearly 1.2 million bachelor's degrees in 1993 (Stringer, 2000/2001). What did these graduates do with their earned degrees? The Bureau of Labor Statistics (BLS) analyzed the data for B.S. graduates in the class of 1993 and placed them into 11 study fields (Stringer, 2000/2001). Those fields include biological sciences, business and management, education, engineering, health professions, history, humanities, mathematics (computer science and physical sciences), psychology, public affairs and social services, and social sciences. Animal science graduates were included in the biological science field. Students in the other field areas were able to find work related to their major more readily than graduates from the biological sciences. Entry-level jobs in a number of the arts and science fields require at least a master's degree (Stringer, 2000/2001). This resulted in graduates with a bachelor's degree in professional fields such as business, management, education, engineering, social services, and health professions having a higher work force than those with a degree in the science fields. According to the research done by Stringer in 2000/2001, "biological science majors, conversely, had the lowest full-time employment rate (57\%) and the highest proportions of graduates unemployed (5\%) and not in the labor force (28\%)" (p. 16) of the 11 fields studied.

Graduates from the class of 1993 were asked if they believed their jobs required a degree, were major related, and if the job had a career potential four years after graduation. Sixty-two percent felt their job required a degree and more than half felt their job was related to their major and had career potential. Stringer (2000/2001) noted that graduates who majored in professional fields responded more positively to the question than did the arts and sciences majors. 
Another finding of the study was related to graduates who were pursuing an advanced degree. Of those 1993 graduates, the most common areas studied were education and business management. Stringer (2000/2001) also found that graduates' employment and enrollment status were also related to academic performance. Graduates with a GPA of 3.5 or higher were more than twice as likely to be in graduate school or in the work force than those graduates with a 3.0 GPA or less.

For the first time in many years, a Bureau of Labor Statistics (BLS) analysis found that total projected college-level job openings between 1998 and 2008 nearly equaled the number of college-educated entrants to the labor force (Fleetwood \& Shelley, 2000). The reason for this abundance of job expectations was gifts from the "baby boomers," those born between 1946 and 1964, in college level jobs. Fleetwood and Shelley (2000) state for students that graduated in the year 1998, "few were employed in the agriculture occupation group; college graduate employment in this group was concentrated in farmer and farm manager occupations. Professional specialty occupations provided nearly 15 million jobs, which include teaching, engineering, nursing, computer systems analysts, and scientists. Prospective students should consider factors such as which occupations offer the most college level jobs and what jobs are tailored to the students' particular skills and aptitudes (Fleetwood \& Shelley, 2000). Fleetwood and Shelly stated, "some college graduates are unable to find college-level jobs because their academic skills were marginal or because their major field of study did not prepare them for college-level jobs that were in demand" (p. 3).

In a study conducted at the University of California-Davis, Meyer (1990) surveyed 1,398 Animal Science Department alumni who had graduated during the years 1956-1987. He found that approximately half of the alumni were situated in one of three careers: veterinarian, 
laboratory or medical scientist, or business owner or manager. Sixty-one percent had advanced degrees such as a teaching credential, master's degree, professional doctorate or Ph.D. Women accounted for slightly over half of the population and were the major participants in all the alumni careers. There also was a large increase in the field of laboratory and medical scientists over the other fields.

For the most part, the animal science alumni were satisfied with their current career choices. Satisfaction was higher for the careers of those working in colleges or universities. Meyers' data (1990) showed that $86 \%$ of those who said the animal science major was relevant to their career were very satisfied with their current career. At the same time, $70 \%$ did not think that animal science was relevant to their current career but were very satisfied with their current career choice. Alumni indicated that the overall preparation of their education was excellent. In fact, $98 \%$ reported that it was adequate. (Meyer, 1990) Preparation that was thought to be more than adequate was stated from veterinarians, dentists, lawyers, those in government or military professions, ranch owners, physicians, owners and store managers. Advanced biology courses and academic skill were ranked first when alumni were asked what was most important to them as an undergraduate to their current career choice. When asked which course requirements were the most helpful to their current career, the most relevant reported courses were animal science courses. The second choice was social science or biological sciences. Veterinarians, farmers, ranchers, educators, and students in advanced-degree programs ranked the importance of animal science courses very high (Meyer, 1990). Alumni recommended more hands-on experiences, work experience, laboratories, field trips and discussions. Alumni mentioned a need for more information dealing with career planning and counseling. More courses in business and economics also were mentioned. Farmers, ranchers, business owners, and managers rated 
business and economics courses higher. As with the alumni, the greatest interest of the entering freshmen was in attaining professional degrees, primarily in veterinary medicine, although a sizeable number changed to biological sciences to pursue medical degrees (Meyer, 1990). The students reported interest in more than one animal species. These included livestock, companion animals, and zoo animals. This indicated that the focus on livestock animals did not coincide with the interests of the students. This was one of the reasons that students left the program. They did not understand the emphasis on livestock and the requirements of the major. The opinion expressed from the animal science alumni was that there was too much emphasis on livestock and not enough on other animals.

The demand for college graduates depends on a number of factors. These factors include the growth of occupations in which many college graduates are employed traditionally, upgrading of skills in jobs that were once non-college level, and the need to replace retired college graduates (Fleetwood \& Shelley, 2000). Jobs for some college graduates are expected to increase by nearly $28 \%$ leading to the requirement of at least a bachelor's degree. The employment in jobs such as professional specialty and technician is expected to grow rapidly through the year 2008 (Fleetwood \& Shelley, 2000). Professional specialty jobs will account for over half of the 8 million jobs that will become available between 1998 and 2008. Research has also shown that an individual's initial job placement is critical in determining status and earnings attained in later career positions (Mau, 2001). Although employment outlook will improve over the years to come, on average more than 90,000 college graduates each year will enter a job position that does not require the skills learned from a bachelor's degree program (Fleetwood \& Shelley, 2000). These college graduates will most likely enter positions including retail sales worker, waiter or waitress, mechanic, records processing and bank teller among many others 
(Fleetwood \& Shelley, 2000). Research has also shown that an individual's initial job placement is critical in determining status and earnings attainment in later career positions (Mau, 2001). 


\section{CHAPTER III \\ METHODOLOGY}

\section{Purpose of the Study}

The primary purpose of this study was to examine career opportunities for graduates completing a Bachelor of Science degree in Animal and Veterinary Sciences at West Virginia University.

$\underline{\text { Specific Objectives }}$

The objectives of the study were to: (1) identify the type and selected factors associated with the first career/occupational status of recent graduates and to (2) identify the type and selected factors associated with the current career/occupational status of recent graduates.

\section{$\underline{\text { Research Questions }}$}

1. What career/occupation did graduates take upon completion of a Bachelor of Science degree in Animal and Veterinary Sciences?

2. How long did graduates stay in their first career position after completion of a Bachelor of Science degree in Animal and Veterinary Sciences?

3. Were graduates satisfied with their first career position after completion of a Bachelor of Science degree in Animal and Veterinary Sciences?

4. What was the starting salary for graduates' first career position after completion of a Bachelor of Science degree in Animal and Veterinary Sciences?

5. What attributes were important in their first career position after completion of a Bachelor of Science degree in Animal and Veterinary Sciences?

6. What was the current career/occupation of Animal and Veterinary Sciences graduates? 
7. How long had Animal and Veterinary Sciences graduates been in their current careers/occupations?

8. Were Animal and Veterinary Sciences graduates satisfied with their current career positions?

9. What was the current salary for Animal and Veterinary Sciences graduates?

10. Have Animal and Veterinary Sciences graduates completed any postgraduate education? $\underline{\text { Research Design }}$

A descriptive research design was selected to collect the data necessary to satisfy the research questions. "Descriptive research methodology provides for the generation of large amounts of data in a limited time frame" (Kaplin, 1991, p. 24). "Descriptive data are usually collected by using observations, interviews, and questionnaires. Descriptive studies range from simple surveys to studies that present explicit statements about the relationships between variables which approach the level of explanatory hypothesis on finds in experimental research" (VanDalen, 1979, p. 285).

Population and Sample

The target population consisted of all West Virginia University alumni who graduated between the years 1991 through 2001 with a Bachelor of Science degree in animal and veterinary science. A census of the alumni was used for the study resulting in the accessible population was identical to the target population.

Sampling errors were avoided by using the entire population of animal science alumni. The list was reviewed for duplication. Frame error was avoided by using official address lists for Davis College students. Instrument content validity and reliability were established to reduce and/or eliminate measurement error. Follow-up procedures recommended by Dillman (1978) 
were used to reduce/eliminate non-response error. Characteristics of early and late respondents (Miller and Smith, 1983) were compared to identify if non-response error had occurred. Selection error was avoided by using a census collection.

$\underline{\text { Instrumentation }}$

The questionnaire was adapted from an existing instrument developed by Meyer (1990) in a similar study titled, Influence of Alumni Careers and Students' Educational Pathways on Animal Science Undergraduate Teaching Programs. The questionnaire included: questions relating to postgraduate education, first career position, most important attributes to their career, current career position, and postgraduate education. A total of 26 questions were included in the questionnaire.

Initial validity and reliability of the instrument was established by Meyer (1990). The revised questionnaire was examined for content validity by a panel of agricultural education and animal science faculty at West Virginia University's Davis College of Agriculture, Forestry, and Consumer Sciences. Cronbachs' alpha reliability coefficients were calculated to determine if the instrument maintained its reliability for the WVU alumni population. Reliability for the WVU alumni population was .728 .

\section{Data Collection Procedures}

After review by the panel of experts, a human subjects exemption was requested from West Virginia University Institutional Review Board (IRB). The IRB reviewed the cover letter and questionnaire to certify that research procedures met all human subjects regulations and that the research was exempted from further IRB research protocol.

An initial packet consisting of a cover letter stating the purpose of the study (Appendix A), the questionnaire (Appendix B) and a stamped, self-addressed envelope was mailed to each 
member of the accessible population on June 10, 2002. The respondents were given 10 days to respond to the survey.

The cover letter explained the research study, why their participation was important, instructions for returning the completed survey, assurance of confidentiality, and a nonobligation statement. Surveys were coded for the purpose of sending reminder post cards.

Thirty-five days after the initial surveys were mailed, a second packet with a cover letter imploring the participants to respond was sent to each non-respondent, and a second deadline was established. The second packet contained a cover letter stating the purpose of the study, the questionnaire, and a stamped, self-addressed envelope. Early and late respondents were tracked. $\underline{\text { Analysis of Data }}$

Returned questionnaires were visually verified for accuracy and completeness and entered in a Microsoft Excel spreadsheet. The data were transferred to the personal computer version of the Statistical Package for the Social Sciences (SPSS). Descriptive statistics used for data analysis included frequencies, means and standard deviations to describe and analyze the population.

\section{$\underline{\text { Use of Findings }}$}

Findings of this study may be used in the Division of Animal and Veterinary Sciences at West Virginia University. The study can be used to inform students in this field of the varied career/occupational opportunities. Starting salaries can be identified for students earning a Bachelor of Science degree in Animal and Veterinary Science. Post-graduate degrees that alumni reported to have earned also are identified. 


\section{CHAPTER IV}

\section{FINDINGS}

\section{Purpose of the Study}

The primary purpose of this study was to examine career opportunities for graduates completing a Bachelor of Science in Animal and Veterinary Sciences at West Virginia University. Data obtained from this study will be useful in providing information on career opportunities to students in the animal science program at West Virginia University prior to graduation and while looking for employment.

\section{Specific Objectives}

Specific objectives included: 1) to identify the type and selected factors associated with the first and current career/occupational status of recent graduates and 2) to determine if graduates were satisfied with their first and current career choice. The study also comprised of demographical data and specific attributes of importance relating to importance in the first career position.

\section{$\underline{\text { Research Questions }}$}

The research questions to be answered were:

1. What career/occupation did graduates take upon completion of a Bachelor of Science degree in Animal and Veterinary Sciences?

2. How long did graduates stay in their first career position after completion of a Bachelor of Science degree in Animal and Veterinary Sciences?

3. Were graduates satisfied with their first career position after completion of a Bachelor of Science degree in Animal and Veterinary Sciences? 
4. What was the starting salary for graduates' first career position after completion of a Bachelor of Science degree in Animal and Veterinary Sciences?

5. What attributes were important in their first career position after completion of a Bachelor of Science degree in Animal and Veterinary Sciences?

6. What was the current career/occupation of Animal and Veterinary Sciences graduates?

7. How long had Animal and Veterinary Sciences graduates been in their current careers/occupations?

8. Were Animal and Veterinary Sciences graduates satisfied with their current career position?

9. What was the current salary for Animal and Veterinary Sciences graduates?

10. Have Animal and Veterinary Sciences graduates completed any postgraduate education? The presentation of these findings is divided into three major parts. First, data pertaining to the first career position will be presented, then the current career position and finally the postgraduate education.

Population

The population consisted of 350 university students who graduated with Bachelor of Science degrees in Animal and Veterinary Sciences from the Davis College of Agriculture and Forestry and Consumer Sciences from 1991-2001. Seventy-four of the 350 mailed surveys were returned due to invalid or out-of-date addresses making the accessible population $\mathrm{N}=276$. A total of 147 surveys were returned with usable data resulting in a response rate of $63 \%$.

During the data analysis phase of the project an error was discovered in the way students responded to the survey. Although the open-ended questions clearly asked for first and current careers, many respondents erroneously indicated that student was their first and/or current career. 
To compensate for this error, two additional data analysis steps were taken. During the second phase of data analysis, the population was divided into two groups, students who had completed or were enrolled in a post-graduate degree program and those students who were had not completed and were not enrolled in a post-graduate degree program. During the third phase of the data analysis process, the population was divided into two groups, students who graduated between 1991 and 1996 and students who graduated between 1997 and 2001. The division of the groups was based on the fact that many professional degrees would take four years to complete.

To meet IRB regulations, respondents were told that they did not have to answer every question on the survey. As a result, the number of respondents for each question varied.

Ninety-two of the respondents (63\%) were female, while $54(37 \%)$ were male (see Table 1). In the 11 year period the number of graduates per year ranged from seven in 1994 to 24 in 2000. Of the 83 respondents from the years 1997-2001, 57 respondents (68.7\%) were female and 26 respondents $(31.3 \%)$ were male. Of the 63 respondents from the years 1991-1996, 35 respondents $(55.6 \%)$ were female and 28 respondents $(44.4 \%)$ were male. For the respondents answering yes to having a post-graduate degree, 55 (58.8\%) were female and $39(41.5 \%)$ were male.

\section{$\underline{\text { First Career }}$}

Students were asked what their first career was after completing their bachelor's degree. Many of the respondents misinterpreted the question and listed student as their first career. In their first careers, approximately $47 \%$ of the alumni were in one of five occupations: 19 (12.9\%) 
Table 1

Gender and Year Graduated of West Virginia University's Animal and Veterinary Sciences

Graduates - 1991-2001

\begin{tabular}{|c|c|c|}
\hline \multirow[t]{3}{*}{ Total } & Post-Graduate & WVU Graduation \\
\hline & Degree & Date \\
\hline & Yes & $1997-01$ \\
\hline
\end{tabular}

Gender

Male

Female

Year Graduated from WVU

\begin{tabular}{lccccccccccc}
1991 & 9 & 6.2 & 5 & 5.3 & 4 & 8.3 & 0 & 0.0 & 9 & 14.3 \\
1992 & 10 & 6.8 & 7 & 7.4 & 3 & 6.3 & 0 & 0.0 & 10 & 15.9 \\
1993 & 10 & 6.8 & 8 & 8.5 & 2 & 4.2 & 0 & 0.0 & 10 & 15.9 \\
1994 & 7 & 4.8 & 4 & 4.3 & 3 & 6.3 & 0 & 0.0 & 7 & 11.1 \\
1995 & 16 & 11.0 & 12 & 12.8 & 4 & 8.3 & 0 & 0.0 & 16 & 25.4 \\
1996 & 11 & 7.5 & 6 & 6.4 & 5 & 10.4 & 0 & 0.0 & 11 & 17.5 \\
1997 & 20 & 13.7 & 15 & 16.0 & 5 & 10.4 & 20 & 24.1 & 0 & 0.0 \\
1998 & 10 & 6.8 & 5 & 5.3 & 5 & 10.4 & 10 & 12.0 & 0 & 0.0 \\
1999 & 9 & 6.2 & 5 & 5.3 & 3 & 6.3 & 9 & 10.8 & 0 & 0.0 \\
2000 & 24 & 16.4 & 12 & 12.8 & 9 & 18.8 & 24 & 28.9 & 0 & 0.0 \\
2001 & 20 & 13.7 & 15 & 16.0 & 5 & 10.4 & 20 & 24.1 & 0 & 0.0 \\
\hline
\end{tabular}

$\begin{array}{llllllllll}54 & 37.0 & 39 & 41.5 & 15 & 31.3 & 26 & 31.3 & 28 & 44.4\end{array}$

$\begin{array}{llllllllll}92 & 63.0 & 55 & 58.5 & 33 & 68.8 & 57 & 68.7 & 35 & 55.6\end{array}$ 
were "other" student, $16(10.9 \%)$ were veterinary students, $12(8.2 \%)$ were in livestock

production/management, $12(8.2 \%)$ were veterinary assistants, and $11(7.9 \%)$ were veterinarians (see Table 2). Teaching and extension had nine respondents (6.1\%). Eight (5.4\%) respondents identified their first career as being a doctor. Another 8 (5.4\%) respondents identified their first career as lab scientist or technician. Eight (5.4\%) respondents reported working in sales/retail. Medical student had six respondents (4.1\%). Five (3.4\%) respondents reported their first career in medical/health care. Three $(2.0 \%)$ respondents were in research or had an internship. Two (1.4\%) respondents owned their own business and two were also dental students. One respondent $(0.7 \%)$ reported being a pharmacist. Fifteen $(10.2 \%)$ respondents were involved in miscellaneous careers, including account executive and computer program analyst.

\section{First Career Based on Post-Graduate Degree}

After separating the respondents into those who have a post-graduate degree and those who did not get a post-graduate degree, the most frequently occurring careers were found for each. The three most frequently occurring careers for the respondents that answered yes to a post-graduate degree were "other" student with $16(17.0 \%)$ respondents, veterinary student with $13(13.8 \%)$ respondents, and veterinarian with $11(11.7 \%)$ respondents (see Table 2$)$. The five most frequently occurring careers for the respondents that answered no to a post-graduate degree were livestock production/management with 10 (20.8\%) respondents, veterinary assistant/technician with six (12.5\%) respondents, and lab scientist/technician, sales/retail, and teaching/extension with four $(8.3 \%)$ respondents each.

\section{$\underline{\text { First Career Based on Year Graduated }}$}

The three most frequently occurring first careers for graduates between 1997 and 2001 were "other" student (17.9\%), veterinary student (14.3\%), and veterinary assistant/technician 
Table 2

First Career of West Virginia University's Animal and Veterinary Sciences Graduates - 19912001

\begin{tabular}{|c|c|c|c|c|c|c|c|c|c|c|}
\hline & \multicolumn{2}{|c|}{ Total } & \multicolumn{4}{|c|}{$\begin{array}{l}\text { Post-Graduate } \\
\text { Degree }\end{array}$} & \multicolumn{4}{|c|}{$\begin{array}{l}\text { WVU Graduation } \\
\text { Date }\end{array}$} \\
\hline & & & \multicolumn{2}{|c|}{ Yes } & \multicolumn{2}{|l|}{ No } & \multicolumn{2}{|c|}{ 1997-01 } & \multicolumn{2}{|c|}{$1991-96$} \\
\hline & $f$ & $\%$ & $f$ & $\%$ & $f$ & $\%$ & $f$ & $\%$ & $f$ & $\%$ \\
\hline Business - Including Owner & 2 & 1.4 & 1 & 1.1 & 1 & 2.1 & 1 & 1.2 & 1 & 1.6 \\
\hline Doctor & 8 & 5.4 & 8 & 8.5 & 0 & 0.0 & 1 & 1.2 & 7 & 11.1 \\
\hline Lab Scientist - Technician & 8 & 5.4 & 4 & 4.3 & 4 & 8.3 & 3 & 3.6 & 5 & 7.9 \\
\hline Livestock Production-Management & 12 & 8.2 & 2 & 2.1 & 10 & 20.8 & 4 & 4.8 & 8 & 12.7 \\
\hline Medical - Health Care & 5 & 3.4 & 4 & 4.3 & 1 & 2.1 & 0 & 0.0 & 5 & 7.9 \\
\hline Pharmacist & 1 & 0.7 & 0 & 0.0 & 1 & 2.1 & 0 & 0.0 & 1 & 1.6 \\
\hline Research - Internship & 3 & 2.0 & 2 & 2.1 & 1 & 2.1 & 2 & 2.4 & 1 & 1.6 \\
\hline Sales - Retail & 8 & 5.4 & 4 & 4.3 & 4 & 8.3 & 3 & 3.6 & 5 & 7.9 \\
\hline Student - Dental & 2 & 1.4 & 2 & 2.1 & 0 & 0.0 & 1 & 1.2 & 1 & 1.6 \\
\hline Student - Medical & 6 & 4.1 & 5 & 5.3 & 0 & 0.0 & 3 & 3.6 & 3 & 4.8 \\
\hline Student - Veterinary & 16 & 10.9 & 13 & 13.8 & 0 & 0.0 & 12 & 14.3 & 4 & 6.3 \\
\hline Student - Other & 19 & 12.9 & 16 & 17.0 & 3 & 6.3 & 15 & 17.9 & 4 & 6.3 \\
\hline Teaching - Extension & 9 & 6.1 & 4 & 4.3 & 4 & 8.3 & 6 & 7.1 & 3 & 4.8 \\
\hline Veterinarian & 11 & 7.5 & 11 & 11.7 & 0 & 0.0 & 4 & 4.8 & 7 & 11.1 \\
\hline Veterinary Technician - Assistant & 12 & 8.2 & 6 & 6.4 & 6 & 12.5 & 8 & 9.5 & 4 & 6.3 \\
\hline Miscellaneous & 15 & 10.2 & 4 & 4.3 & 11 & 22.9 & 12 & 14.3 & 3 & 4.8 \\
\hline Missing & 10 & 6.8 & 8 & 8.5 & 2 & 4.2 & 9 & 10.7 & 1 & 1.6 \\
\hline
\end{tabular}


(9.5\%). The three most frequently occurring first careers for graduates between 1991 and 1996 were livestock production/management (12.7\%), doctor (11.1\%), and veterinarian (11.1\%).

First Career in Field of Choice

Respondents were asked if their first career was in the field of their choice. Of the 126 graduates that responded to this question $89(70.6 \%)$ said that their first career was in the field of their choice (see Table 3). Thirty-seven respondents (29.4\%) indicated their first career was not in their field of their choice.

Field of Choice Based on Post-Graduate Degree

For graduates answering yes to having a post-graduate degree, $61(79.2 \%)$ respondents' first career was in their field of choice and $16(20.8 \%)$ respondents said that their first career was not in their field of choice. For the graduates answering no to having a post-graduate degree, 27 (57.4\%) reported that their first career was in their field of choice and $20(42.6 \%)$ respondents said that their first career was not in their field of choice.

Field of Choice Based on Year Graduated

For respondents who graduated between 1991 and 1996, 45 (72.6\%) respondents' first career was in their field of choice and $17(27.4 \%)$ respondents said that their first career was not in their field of choice. For respondents who graduated between 1997 and 2001, 44 (68.8\%) respondents' first career was in their field of choice and $20(31.3 \%)$ respondents said that their first career was not in their field of choice.

\section{Time to Secure and Length of First Career}

The length of time that it took graduates to enter their first career after receiving their Bachelor's degree ranged from zero months to nine years, an average of 10.43 months (see Table 4). Extreme scores affect the mean variable, so the median length of time it took respondents to 
Table 3

Was the First Career of West Virginia University's Animal and Veterinary Sciences Graduates 1991-2001 in their Field of Choice?

\begin{tabular}{|c|c|c|c|c|c|c|c|c|c|c|}
\hline & \multicolumn{2}{|c|}{ Total } & \multirow{2}{*}{\multicolumn{4}{|c|}{$\begin{array}{c}\text { Post-Graduate } \\
\text { Degree }\end{array}$}} & \multirow{2}{*}{\multicolumn{4}{|c|}{$\begin{array}{c}\text { WVU Graduation } \\
\text { Date }\end{array}$}} \\
\hline & & & & & & & & & & \\
\hline & & & \multicolumn{2}{|l|}{ Yes } & \multicolumn{2}{|l|}{ No } & \multicolumn{2}{|c|}{ 1997-01 } & \multicolumn{2}{|c|}{ 1991-96 } \\
\hline & $f$ & $\%$ & $f$ & $\%$ & $f$ & $\%$ & $f$ & $\%$ & $f$ & $\%$ \\
\hline Yes & 89 & 70.6 & 61 & 79.2 & 27 & 57.4 & 44 & 68.8 & 45 & 72.6 \\
\hline No & 37 & 29.4 & 16 & 20.8 & 20 & 42.6 & 20 & 31.3 & 17 & 27.4 \\
\hline
\end{tabular}

enter their first career after receiving the Bachelor's degree, two months is more representative. The length of time respondents stayed in their first career ranged from zero to fifteen years, an average of 2.79 years.

Table 4

Time to Secure and Length of First Career for West Virginia University's Animal and Veterinary Sciences Graduates - 1991-2001

\begin{tabular}{lcccccc}
\hline & $N$ & Minimum & Maximum & $M$ & $M D$ & $S D$ \\
& & & & & & \\
\hline Months Following Graduation & 118 & .00 & 108 & 10.43 & 2.0 & 19.63 \\
Years in First Career & 118 & .00 & 15.00 & 2.79 & 2.0 & 2.57 \\
\hline
\end{tabular}

\section{First Career Satisfaction}

Using a five point Likert scale, graduates were asked about their level of satisfaction with their first career. The response options ranged from 1 , representing very dissatisfied, to 5 , 
representing very satisfied. Overall, more than half of the respondents $(61.6 \%)$ were satisfied with their first career (see Table 5). Forty-eight (38.4\%) respondents reported being very satisfied with their first career. Twenty-nine (23.3\%) respondents were satisfied with their careers. Thirty-three $(26.4 \%)$ of the respondents had mixed feelings about their first career. Eight respondents $(6.4 \%)$ were dissatisfied with their career. Only seven $(5.6 \%)$ respondents were very dissatisfied with their first career.

First Career Satisfaction Based on Post-Graduate Degree

For the graduates answering yes to a post-graduate degree, $50(65.8 \%)$ respondents were satisfied with their first career and eight $(10.5 \%)$ respondents were dissatisfied with their first career (see Table 5). For the graduates answering no to a post-graduate degree, $25(53.1 \%)$ respondents were satisfied with their first career and seven (14.9\%) respondents were dissatisfied with their first career.

\section{First Career Satisfaction Based on Year Graduated}

For the respondents who graduated between 1991 and 1996, 40 (64.5\%) respondents were satisfied with their first career and eight (12.9\%) respondents were dissatisfied with their first career (see Table 5). For the respondents who graduated between 1997 and 2001, 37 $(58.7 \%)$ respondents were satisfied with their first career and seven $(11.1 \%)$ respondents were dissatisfied with their first career.

\section{First Career Starting Salary}

Using $\$ 5,000$ incremental categories, respondents were asked to indicate their starting salary for their first career. Over half of the respondents $(52.6 \%)$ had a starting salary of under $\$ 24,999$ (see Table 6). Eighteen $(15.3 \%$ ) respondents starting salary was under $\$ 10,000$. 
Table 5

First Career Satisfaction of West Virginia University's Animal and Veterinary Sciences

Graduates - 1991-2001

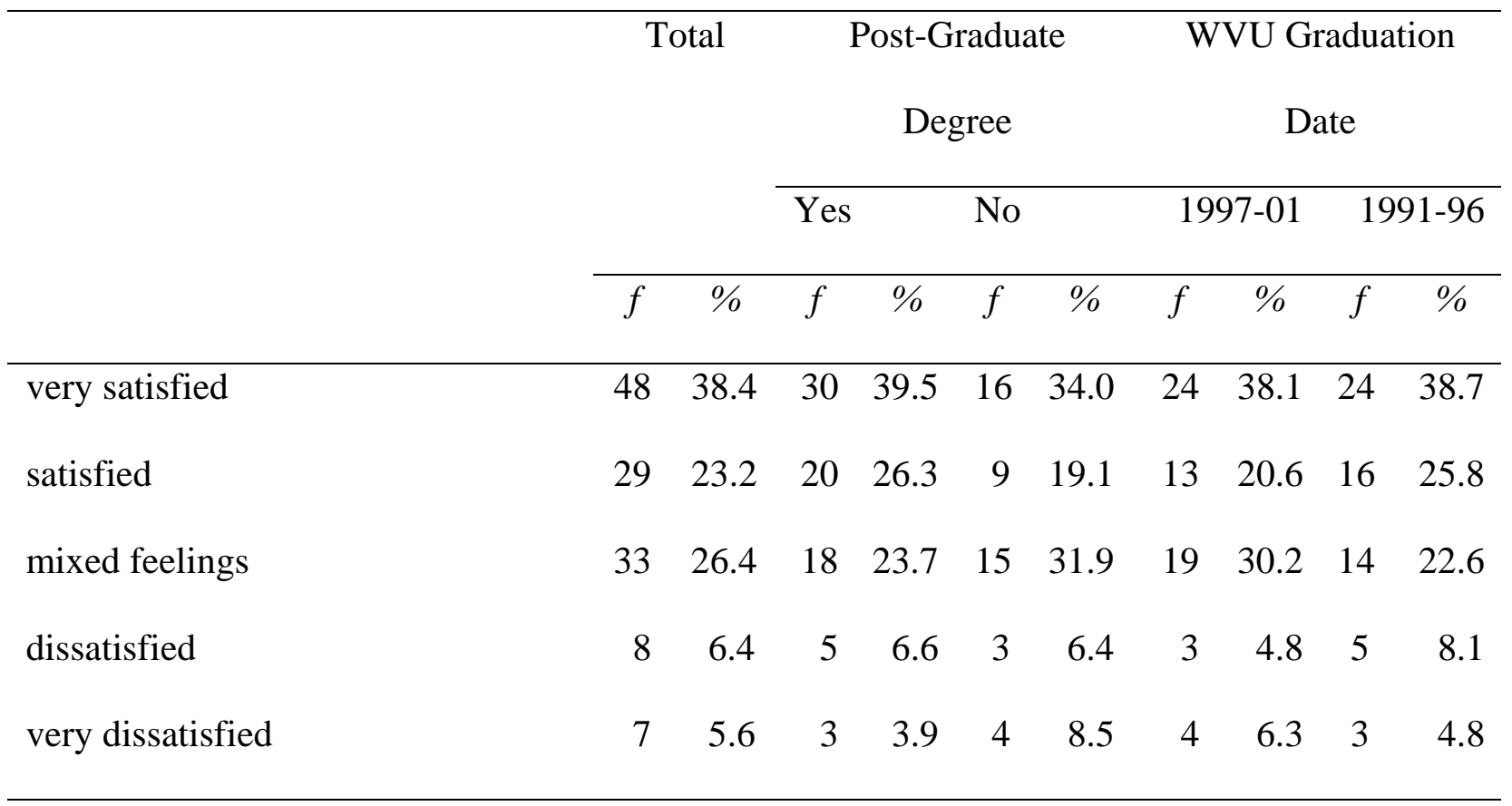

Starting salary between $\$ 10,000$ and $\$ 14,999$ had 14 (11.9\%) respondents. Fifteen $(12.7 \%)$ respondents' starting salary was between $\$ 15,000$ and $\$ 19,999$. Another 15 (12.7\%) respondents' starting salary was between $\$ 20,000$ and $\$ 24,999$. Forty-two respondents' (42.4\%) starting salary was between $\$ 25,000$ and $\$ 54,999$. Starting salary between $\$ 25,000$ and $\$ 29,000$ had $13(11.0 \%)$ respondents. Eight (6.8\%) respondents' starting salary was between $\$ 30,000$ and $\$ 34,999$. Thirteen $(11.0 \%)$ respondents' starting salary was between $\$ 35,000$ and $\$ 39,999$. Four (3.4\%) respondents' starting salary was between $\$ 40,000$ and $\$ 44,999$. Another four (3.4\%) respondents' starting salary was between $\$ 50,000$ and $\$ 54,999$. Starting salary of $\$ 55,000$ and above had six respondents (4.9\%). Salaries based on career/occupations was configured (Appendix D). 


\section{$\underline{\text { First Career Starting Salary Based on Post-Graduate Degree }}$}

After separating the respondents into those who have a post-graduate degree and those who did not get a post-graduate degree the three most frequently occurring first career starting salaries were found for each. The three most frequently occurring first career starting salaries for the respondents that answered yes to a post-graduate degree were under \$10,000 with $14(20.0 \%)$ respondents, between $\$ 35,000$ and $\$ 39,999$ with $11(15.7 \%)$ respondents, and between $\$ 20,000$ and $\$ 24,999$ with eight $(11.4 \%$ ) respondents (see Table 6 ). The three most frequently occurring first career starting salaries for the respondents that answered no to a post-graduate degree were between $\$ 15,000$ and $\$ 19,999$ with ten $(21.3 \%$ ) respondents, between $\$ 25,000$ and $\$ 29,999$ with eight (17.0\%) respondents and between $\$ 10,000$ and $\$ 14,999$ with eight (17.0\%) respondents. The most frequently occurring career starting salary for respondents from 1997 to 2001 was under $\$ 10,000$ and the most frequently occurring first career starting salary for respondents from 1991 to 1996 was $\$ 35,000$ to $\$ 39,999$.

\section{$\underline{\text { First Career Starting Salary Based on Year Graduated }}$}

The three most frequently occurring starting salaries for respondents who graduated between 1991 and 1996 were $\$ 35,000$ to $\$ 39,999$ (21.3\%), \$20,000 and $\$ 24,999(16.4 \%)$ and $\$ 25,000$ and $\$ 29,999(13.1 \%)$. The three most frequently occurring starting salaries for respondents who graduated between 1997 and 2001 were under \$10,000 (29.8\%), \$10,000 and $\$ 14,999(15.8 \%)$ and $\$ 15,000$ and $\$ 19,999(14.0 \%)$.

\section{Importance of Specific Attributes in the First Career}

Graduates were asked to rate attributes as to their importance in their first career positions. Responses were measured on a four point Likert scale with $1=$ not important, $2=$ somewhat important, $3=$ important, and $4=$ very important (see Table 7 ). Three attributes were 
Table 6

First Career Starting Salary of West Virginia University's Animal and Veterinary Sciences

Graduates - 1991-2001 (n=118)

\begin{tabular}{|c|c|c|c|c|c|c|c|c|c|c|}
\hline & \multicolumn{2}{|c|}{ Total } & \multirow{2}{*}{\multicolumn{4}{|c|}{$\begin{array}{c}\text { Post-Graduate } \\
\text { Degree }\end{array}$}} & \multirow{2}{*}{\multicolumn{4}{|c|}{$\begin{array}{c}\text { WVU Graduation } \\
\text { Date }\end{array}$}} \\
\hline & & \multirow[b]{3}{*}{$\%$} & & & & & & & & \\
\hline & \multirow[b]{2}{*}{$f$} & & \multicolumn{2}{|c|}{ Yes } & \multicolumn{2}{|c|}{ No } & \multicolumn{2}{|c|}{ 1997-01 } & \multicolumn{2}{|c|}{$1991-96$} \\
\hline & & & $f$ & $\%$ & $f$ & $\%$ & $f$ & $\%$ & $f$ & $\%$ \\
\hline Under $\$ 10,000$ & 18 & 15.3 & 14 & 20.0 & 4 & 8.5 & 17 & 29.8 & 1 & 1.6 \\
\hline$\$ 10-000--14,999$ & 14 & 11.9 & 6 & 8.6 & 8 & 17.0 & 9 & 15.8 & 5 & 8.2 \\
\hline$\$ 15,000--19,999$ & 15 & 12.7 & 5 & 7.1 & 10 & 21.3 & 8 & 14.0 & 7 & 11.5 \\
\hline$\$ 20,000--24,999$ & 15 & 12.7 & 8 & 11.4 & 6 & 12.8 & 5 & 8.8 & 10 & 16.4 \\
\hline$\$ 25,000--29,999$ & 13 & 11.0 & 5 & 7.1 & 8 & 17.0 & 5 & 8.8 & 8 & 13.1 \\
\hline$\$ 30,000--34,999$ & 8 & 6.8 & 4 & 5.7 & 4 & 8.5 & 6 & 10.5 & 2 & 3.3 \\
\hline$\$ 35,000--39,999$ & 13 & 11.0 & 11 & 15.7 & 2 & 4.3 & 0 & 0.0 & 13 & 21.3 \\
\hline$\$ 40,000--44,999$ & 8 & 6.8 & 7 & 10.0 & 1 & 2.1 & 2 & 3.5 & 6 & 9.8 \\
\hline$\$ 45,000--49,999$ & 4 & 3.4 & 3 & 4.3 & 1 & 2.1 & 3 & 5.3 & 1 & 1.6 \\
\hline$\$ 50,000--54,999$ & 4 & 3.4 & 3 & 4.3 & 1 & 2.1 & 2 & 3.5 & 2 & 3.3 \\
\hline$\$ 55,000--59,999$ & 2 & 1.7 & 2 & 2.9 & 0 & 0.0 & 0 & 0.0 & 2 & 3.3 \\
\hline$\$ 70,000--74,999$ & 1 & 0.8 & 0 & 0.0 & 1 & 2.1 & 0 & 0.0 & 1 & 1.6 \\
\hline$\$ 75,000--79,999$ & 1 & 0.8 & 0 & 0.0 & 1 & 2.1 & 0 & 0.0 & 1 & 1.6 \\
\hline$\$ 80,000--84,999$ & 1 & 0.8 & 1 & 1.4 & 0 & 0.0 & 0 & 0.0 & 1 & 1.6 \\
\hline$\$ 100,000 \&$ above & 1 & 0.8 & 1 & 1.4 & 0 & 0.0 & 0 & 0.0 & 1 & 1.6 \\
\hline
\end{tabular}


rated as very important ( $M$ greater than 3.5). Respondents indicated that the most important attribute in their first career was the ability to work with people $(M=3.71)$. Ability to gain and use knowledge $(M=3.66)$ and verbal communication skills $(M=3.66)$ were also rated as very important attributes. Respondents rated seven attributes as important ( $M$ between 2.5 and 3.49). Problem solving ability ranked fourth $(M=3.44)$, technical information fifth $(M=3.33)$, written communication skills sixth $(M=3.13)$, and seventh was leadership skills $(M=3.03)$. Also included in the important category were computer and technical skills $(M=2.86)$, managerial ability $(M=2.73)$, and cross-cultural understanding $(M=2.61)$. Concern for the environment was rated as somewhat important ( $M$ between 1.5 and 2.49). $(M=2.47)$.

$\underline{\text { Importance of Specific Attributes in the First Career Based on Post-Graduate Degree }}$

The three most frequently occurring attributes in the first career remained the same for graduates that answered yes to having a post-graduate degree and for the graduates that answered no (see Table 7). Ability to work with people $(M=3.76)$, ability to gain and use knowledge $(M$ $=3.76)$ and verbal communication skills $(M=3.76)$ were rated equally by students who answered yes to having a post-graduate degree. Ability to work with people $(M=3.64)$, ability to gain and use knowledge $(M=3.49)$ and verbal communication skills $(M=3.49)$ were also rated as the top three attributes by students who answered no to having a post-graduate degree. Importance of Specific Attributes in the First Career Based on Year Graduated

The three most frequently occurring attributes in the first career remained the same for graduates based upon the years graduated (see Table 7). Ability to work with people $(M=3.64)$, ability to gain and use knowledge $(M=3.63)$ and verbal communication skills $(M=3.59)$ were rated as the three most frequently occurring attributes by students who graduated between 1991 and 1996. Ability to work with people $(M=3.76)$, verbal communication skills $(M=3.72)$, and 
ability to gain and use knowledge $(M=3.69)$ were rated as the three most frequently occurring attributes by students who graduated between 1997 and 2001 .

Table 7

Rating of the Importance of Specific Attributes in the First Career of of West Virginia

University’s Animal and Veterinary Sciences Graduates - 1991-2001

\begin{tabular}{|c|c|c|c|c|c|c|c|c|c|c|}
\hline & \multicolumn{2}{|c|}{ Total } & \multicolumn{4}{|c|}{ Post-Graduate Degree } & \multicolumn{4}{|c|}{ WVU Graduation Date } \\
\hline & & & Yes & & No & & & $7-01$ & & $91-96$ \\
\hline & $M$ & $S D$ & $M$ & $S D$ & $M$ & $S D$ & $M$ & $S D$ & $M$ & $S D$ \\
\hline Ability to Work with People & 3.71 & .58 & 3.76 & .54 & 3.64 & .64 & 3.76 & .52 & 3.64 & .64 \\
\hline $\begin{array}{l}\text { Verbal Communication } \\
\text { Skills }\end{array}$ & 3.66 & .58 & 3.76 & .51 & 3.49 & .66 & 3.69 & .55 & 3.63 & 61 \\
\hline $\begin{array}{l}\text { Ability to Gain and Use } \\
\text { Knowledge }\end{array}$ & 3.66 & .63 & 3.76 & .54 & 3.49 & .75 & 3.72 & .54 & 3.59 & .72 \\
\hline Technical Information & 3.33 & .94 & 3.47 & .88 & 3.09 & 1.02 & 3.35 & .96 & 3.31 & .93 \\
\hline $\begin{array}{l}\text { Written Communication } \\
\text { Skills }\end{array}$ & 3.13 & .98 & 3.29 & .86 & 2.89 & 1.09 & 3.15 & .93 & 3.10 & 1.05 \\
\hline Leadership Skills & 3.03 & .86 & 3.10 & .85 & 2.89 & .88 & 3.09 & .85 & 2.97 & .87 \\
\hline $\begin{array}{l}\text { Computer and Technical } \\
\text { Skills }\end{array}$ & 2.86 & .97 & 2.99 & .86 & 2.64 & 1.11 & 2.97 & .99 & 2.73 & .94 \\
\hline Managerial Ability & 2.73 & .93 & 2.69 & .92 & 2.81 & .92 & 2.78 & .94 & 2.68 & .92 \\
\hline $\begin{array}{l}\text { Cross-Cultural } \\
\text { Understanding }\end{array}$ & 2.61 & .98 & 2.65 & .99 & 2.52 & .96 & 2.64 & 1.01 & 2.58 & .95 \\
\hline $\begin{array}{l}\text { Concern for the } \\
\text { Environment }\end{array}$ & 2.47 & 1.06 & 2.44 & 1.04 & 2.51 & 1.10 & 2.68 & 1.07 & 2.24 & 1.01 \\
\hline
\end{tabular}

Rating Scale: 1= Not Important, 2= Somewhat Important, 3= Important, 4= Very Important 


\section{$\underline{\text { Current Career }}$}

West Virginia University’s Animal and Veterinary Sciences Graduates - 1991-2001 were asked to identify their current careers. Many of the respondents misinterpreted the question and listed student as their current career. The three most frequently occurring careers for alumni were veterinarian $(n=22,15.0 \%)$, were "other" student $(n=21,14.3 \%)$, and doctor $(n=10,6.8 \%)$ (see Table 8). Livestock production/management had nine respondents $(6.1 \%)$. Business/including owner, veterinary student and teaching/extension each had six (4.1\%) respondents. Sales/retail had five (3.4\%) respondents. Lab scientist/technician, medical student, veterinary assistant/technician each had four (2.7\%) respondents each. Twenty-seven respondents (18.4\%) had careers in miscellaneous areas. The miscellaneous category included such areas as account executive, application support specialist, coal miner, database analyst, insurance agent, firefighter, patent examiner, regulatory affairs specialist and U. S. border patrol agent.

\section{$\underline{\text { Current Careers Based on Post-Graduate Degree }}$}

After separating the respondents into those who have a post-graduate degree and those who did not get a post-graduate degree, the most frequently occurring careers were found for each. The three most frequently occurring careers for the respondents that answered yes to a post-graduate degree were veterinarian with $22(23.4 \%)$ respondents, student in the category other with $15(16.0 \%)$ respondents, and doctor with 10 (10.6\%) respondents (see Table 8). The three most frequently occurring careers for the respondents that answered no to a post-graduate degree were livestock production/management with 7 (14.6\%) respondents, sales/retail and student in the other category with four $(8.3 \%)$ respondents each. 
Table 8

Current Career for West Virginia University's Animal and Veterinary Sciences Graduates $1991-2001(\mathrm{n}=132)$

\begin{tabular}{|c|c|c|c|c|c|c|c|c|c|c|}
\hline & \multicolumn{2}{|c|}{ Total } & \multicolumn{4}{|c|}{$\begin{array}{l}\text { Post-Graduate } \\
\text { Degree }\end{array}$} & \multicolumn{4}{|c|}{$\begin{array}{l}\text { WVU Graduation } \\
\text { Date }\end{array}$} \\
\hline & & & \multicolumn{2}{|c|}{ Yes } & \multicolumn{2}{|l|}{ No } & \multicolumn{2}{|c|}{$1997-01$} & \multicolumn{2}{|c|}{$1991-96$} \\
\hline & $f$ & $\%$ & $f$ & $\%$ & $f$ & $\%$ & $f$ & $\%$ & $f$ & $\%$ \\
\hline Business - Including Owner & 6 & 4.1 & 4 & 4.3 & 2 & 4.2 & 2 & 2.4 & 4 & 6.3 \\
\hline Doctor & 10 & 6.8 & 10 & 10.6 & 0 & 0.0 & 1 & 1.2 & 9 & 14.3 \\
\hline Lab Scientist - Technician & 4 & 2.7 & 1 & 1.1 & 3 & 6.3 & 1 & 1.2 & 3 & 4.8 \\
\hline Livestock Production-Management & 9 & 6.1 & 2 & 2.1 & 7 & 14.6 & 5 & 6.0 & 4 & 6.3 \\
\hline Medical - Health Care & 3 & 2.0 & 2 & 2.1 & 1 & 2.1 & 0 & 0.0 & 3 & 4.8 \\
\hline Pharmacist & 1 & 0.7 & 0 & 0.0 & 1 & 2.1 & 0 & 0.0 & 1 & 1.6 \\
\hline Research - Internship & 2 & 1.4 & 0 & 0.0 & 2 & 4.2 & 0 & 0.0 & 2 & 3.2 \\
\hline Sales - Retail & 5 & 3.4 & 1 & 1.1 & 4 & 8.3 & 2 & 2.4 & 3 & 4.8 \\
\hline Student - Dental & 1 & 0.7 & 1 & 1.1 & 0 & 0.0 & 1 & 1.2 & 0 & 0.0 \\
\hline Student -Medical & 4 & 2.7 & 1 & 1.1 & 2 & 4.2 & 3 & 3.6 & 1 & 1.6 \\
\hline Student - Veterinary & 6 & 4.1 & 6 & 6.4 & 0 & 0.0 & 6 & 7.1 & 0 & 0.0 \\
\hline Student - Other & 21 & 14.3 & 15 & 16.0 & 4 & 8.3 & 17 & 20.2 & 4 & 6.3 \\
\hline Teaching - Extension & 6 & 4.1 & 4 & 4.3 & 2 & 4.2 & 4 & 4.8 & 2 & 3.2 \\
\hline Veterinarian & 22 & 15.0 & 22 & 23.4 & 0 & 0.0 & 9 & 10.7 & 13 & 20.6 \\
\hline Miscellaneous & 27 & 18.4 & 12 & 12.8 & 15 & 31.3 & 15 & 17.9 & 12 & 19.0 \\
\hline Veterinary Technician-Assistant & 4 & 2.7 & 2 & 2.1 & 2 & 4.2 & 4 & 4.8 & 0 & 0.0 \\
\hline Dentist & 1 & 0.7 & 1 & 1.1 & 0 & 0.0 & 0 & 0.0 & 1 & 1.6 \\
\hline Missing & 15 & 10.2 & 10 & 10.6 & 3 & 6.3 & 14 & 16.7 & 1 & 1.6 \\
\hline
\end{tabular}




\section{Current Careers Based on Year Graduated}

The three most frequently occurring current careers for graduates between 1997 and 2001 were "other" student (20.2\%), veterinary student (7.1\%), and livestock production/management (6.0\%). The five most frequently occurring current careers for graduates between 1991 and 1996 were veterinarian $(20.6 \%)$, doctor (14.3\%), business/including owner $(6.3 \%)$, livestock production/management $(6.3 \%)$, and "other" student $(6.3 \%)$.

\section{Current Career in Field of Choice}

Graduates were asked if their current career was in the field of their choice. Of the 120 graduates that responded to this question 87 (80.8\%) said their current career was in the field of their choice (see Table 9). Twenty-three respondents (19.2\%) indicated that their current career was not in the field of their choice.

Field of Choice Based on Post-Graduate Degree

For graduates answering yes to having a post-graduate degree, $69(90.8 \%)$ respondents current career was in their field of choice and seven (9.2\%) respondents said that their current career was not in their field of choice (see Table 9). For the graduates answering no to having a post-graduate degree, $27(62.8 \%)$ reported that their current career was in their field of choice and $16(37.2 \%)$ respondents said that their current career was not in their field of choice.

\section{Field of Choice Based on Year Graduated}

Fifty-three (89.9\%) of the respondents who graduated between 1991 and 1996 indicated their current career was in the field of their choice. Forty-four $(74.6 \%)$ of the respondents who graduated between 1997 and 2001 indicated their current career was in the field of their choice. 
Table 9

Was the Current Career of West Virginia University's Animal and Veterinary Sciences

Graduates - 1991-2001 in their Field of Choice? $(\mathrm{n}=120)$

\begin{tabular}{|c|c|c|c|c|c|c|c|c|c|c|}
\hline & & tal & & ost-G & $\mathrm{cadu}$ & & & $V U G$ & idua & ion \\
\hline & & & & De & ree & & & & & \\
\hline & & & Yes & & No & & & 7-01 & 19 & $91-96$ \\
\hline & $f$ & $\%$ & $f$ & $\%$ & $f$ & $\%$ & $\bar{f}$ & $\%$ & $\bar{f}$ & $\%$ \\
\hline Yes & 97 & 80.8 & 69 & 90.8 & 27 & 62.8 & 44 & 74.6 & 53 & 86.9 \\
\hline No & 23 & 19.2 & 7 & 9.2 & 16 & 37.2 & 15 & 25.4 & 8 & 13.1 \\
\hline
\end{tabular}

\section{Length of Time in Current Career}

Graduates were asked to indicate the length of time they had been in their current career.

Graduates' time in their current career ranged from just under one month to fifteen years (see

Table 10). The average length of time in their current career was 2.42 years with a standard deviation of 2.47 years and a median of 1.67 years.

Table 10

Years in Current Career for West Virginia University's Animal and Veterinary Sciences

Graduates - 1991-2001

\begin{tabular}{lcccccc}
\hline & $N$ & Minimum & Maximum & M & MD & $S D$ \\
\hline Years in Second Career & 120 & .08 & 15.00 & 2.42 & 1.67 & 2.47 \\
\hline
\end{tabular}




\section{$\underline{\text { Current Career Satisfaction }}$}

Graduates were asked how satisfied they were with current career. More than threefourths of the respondents $(78.8 \%)$ were satisfied or very satisfied with their current career. Sixty-five (55.1\%) respondents reported being very satisfied with current career (see Table 11). Twenty-eight $(23.7 \%)$ respondents were satisfied with their current career. Twenty (16.9\%) of the respondents had mixed feelings about their current career. Two respondents $(1.7 \%)$ were dissatisfied with their career and three $(2.5 \%)$ respondents were very dissatisfied with their current career.

\section{Current Career Satisfaction Based on Post-Graduate Degree}

For the graduates answering yes to a post-graduate degree, $63(85.1 \%)$ respondents were satisfied with their current career and two $(2.7 \%)$ respondents were dissatisfied with their current career (see Table 11). For the graduates answering no to a post-graduate degree, $29(67.5 \%)$ respondents were satisfied with their current career and three (7.0\%) respondents were dissatisfied with their current career.

\section{Current Career Satisfaction Based on Year Graduated}

For the respondents who graduated between 1991 and 1996, 53 (88.4\%) respondents were satisfied with their current career and none were dissatisfied with their current career (see Table 11). For the respondents who graduated between 1997 and 2001, 40 (69.0\%) respondents were satisfied with their first current and five (8.6\%) respondents were dissatisfied with their current career. 
Table 11

Current Career Satisfaction for West Virginia University's Animal and Veterinary Sciences

Graduates $-1991-2001(\mathrm{n}=118)$

\begin{tabular}{|c|c|c|c|c|c|c|c|c|c|c|}
\hline & \multicolumn{2}{|c|}{ Total } & \multirow{2}{*}{\multicolumn{4}{|c|}{$\begin{array}{c}\text { Post-Graduate } \\
\text { Degree }\end{array}$}} & \multirow{2}{*}{\multicolumn{4}{|c|}{$\begin{array}{c}\text { WVU Graduation } \\
\text { Date }\end{array}$}} \\
\hline & \multirow[b]{3}{*}{$f$} & \multirow[b]{3}{*}{$\%$} & & & & & & & & \\
\hline & & & \multicolumn{2}{|c|}{ Yes } & \multicolumn{2}{|l|}{ No } & \multicolumn{2}{|c|}{ 1997-01 } & \multicolumn{2}{|c|}{ 1991-96 } \\
\hline & & & $f$ & $\%$ & $f$ & $\%$ & $f$ & $\%$ & $f$ & $\%$ \\
\hline very satisfied & 65 & 55.1 & 47 & 63.5 & 18 & 41.9 & 28 & 48.3 & 37 & 61.7 \\
\hline satisfied & 28 & 23.7 & 16 & 21.6 & 11 & 25.6 & 12 & 20.7 & 16 & 26.7 \\
\hline mixed feelings & 20 & 16.9 & 9 & 12.2 & 11 & 25.6 & 13 & 22.4 & 7 & 11.7 \\
\hline dissatisfied & 2 & 1.7 & 0 & 0.0 & 2 & 4.7 & 2 & 3.4 & 0 & 0.0 \\
\hline very dissatisfied & 3 & 2.5 & 2 & 2.7 & 1 & 2.3 & 3 & 5.2 & 0 & 0.0 \\
\hline
\end{tabular}

\section{Current Career Salary}

Graduates were asked to identify their current career salary. Over half of the respondents (52.1\%) had a current career salary under $\$ 39,999$ (see Table 12). Fifteen (13.0\%) respondents reported their current career salary was under $\$ 10,000$. Ten (8.7\%) respondents' current career salary was between $\$ 10,000$ and $\$ 14,999$. Four (3.5\%) respondents' current career salary was between $\$ 15,000$ and $\$ 19,999$. Current career salary between $\$ 20,000$ and $\$ 24,999$ had five (4.3\%) respondents. Ten (8.7\%) respondents' current career salary was between $\$ 25,000$ and $\$ 29,000$. Seven (6.1\%) respondents' current career salary was between $\$ 30,000$ and $\$ 34,999$. The category for current career salary between $\$ 35,000$ and $\$ 39,999$ had nine $(7.8 \%)$ respondents. Thirty-six (31.2\%) respondents' current career salary was in the range of $\$ 40,000$ 
to $\$ 64,999$. Current career salary for nine (7.8\%) respondents was between $\$ 40,000$ and $\$ 44,999$. Another nine (7.8\%) respondents' current career salary was between $\$ 45,000$ and $\$ 49,999$. Eight (7.0\%) respondents' current career salary was between $\$ 50,000$ and $\$ 54,999$. The category for current career salary between $\$ 55,000$ and $\$ 59,999$ had five (4.3\%) respondents. Another five (4.3\%) respondents' current career salary was between $\$ 60,000$ and $\$ 64,999$. Nineteen $(16.5 \%)$ respondents' current career salary was in the range of $\$ 65,000$ to $\$ 100,000$ and above. Current career salary between $\$ 65,000$ and $\$ 69,999$ had one (0.9\%) respondent. Also one (0.9\%) respondent had a current career salary between $\$ 70,000$ and $\$ 74,999$. Five (4.3\%) respondents' current career salary was between $\$ 75,000$ and $\$ 79,999$. The category for current career salary between $\$ 80,000$ and $\$ 84,999$ had three (2.6\%) respondents. Another three (2.6\%) respondents' current career salary was between $\$ 90,000$ and $\$ 94,999$. Six (5.2\%) respondents reported their current career salary as being $\$ 100,000$ and above.

\section{Current Career Salary Based on Post-Graduate Degree}

After separating the respondents into those who have a post-graduate degree and those who did not get a post-graduate degree the three most frequently occurring current career salaries were found for each. The four most frequently occurring current career salaries for the respondents that answered yes to a post-graduate degree were under $\$ 10,000$ with $11(15.1 \%)$ respondents, between $\$ 50,000$ and $\$ 54,999$ with eight (11.0\%) respondents, between $\$ 10,000$ and $\$ 14,999$ with seven (9.6\%) respondents, and between $\$ 45,000$ and $\$ 49,999$ with seven (9.6\%) respondents (see Table 12). The three most frequently occurring current career salaries for the respondents that answered no to a post-graduate degree were between $\$ 25,000$ and $\$ 29,999$ with six (14.3\%) respondents, between $\$ 40,000$ and $\$ 44,999$ with six (14.3\%) respondents and between $\$ 20,000$ and $\$ 24,999$ with five (11.9\%) respondents. The most 
Table 12

Current Career - Salary for West Virginia University's Animal and Veterinary Sciences

Graduates - 1991-2001 (n=115)

\begin{tabular}{|c|c|c|c|c|c|c|c|c|c|c|}
\hline & \multicolumn{2}{|c|}{ Total } & \multicolumn{4}{|c|}{$\begin{array}{c}\text { Post-Graduate } \\
\text { Degree }\end{array}$} & \multicolumn{4}{|c|}{$\begin{array}{c}\text { WVU Graduation } \\
\text { Date }\end{array}$} \\
\hline & & & Yes & & No & & & $7-01$ & & $1-96$ \\
\hline & $f$ & $\%$ & $f$ & $\%$ & $f$ & $\%$ & $f$ & $\%$ & $f$ & $\%$ \\
\hline Under $\$ 10,000$ & 15 & 13.0 & 11 & 15.1 & 4 & 9.5 & 14 & 25.9 & 1 & 1.6 \\
\hline$\$ 10-000--14,999$ & 10 & 8.7 & 7 & 9.6 & 3 & 7.1 & 7 & 13.0 & 3 & 4.9 \\
\hline$\$ 15,000--19,999$ & 4 & 3.5 & 2 & 2.7 & 2 & 4.8 & 3 & 5.6 & 1 & 1.6 \\
\hline$\$ 20,000--24,999$ & 5 & 4.3 & 0 & 0.0 & 5 & 11.9 & 4 & 7.4 & 1 & 1.6 \\
\hline$\$ 25,000--29,999$ & 10 & 8.7 & 4 & 5.5 & 6 & 14.3 & 7 & 13.0 & 3 & 4.9 \\
\hline$\$ 30,000--34,999$ & 7 & 6.1 & 6 & 8.2 & 1 & 2.4 & 4 & 7.4 & 3 & 4.9 \\
\hline$\$ 35,000--39,999$ & 9 & 7.8 & 4 & 5.5 & 5 & 11.9 & 1 & 1.9 & 8 & 13.1 \\
\hline$\$ 40,000--44,999$ & 9 & 7.8 & 3 & 4.1 & 6 & 14.3 & 4 & 7.4 & 5 & 8.2 \\
\hline$\$ 45,000--49,999$ & 9 & 7.8 & 7 & 9.6 & 2 & 4.8 & 3 & 5.6 & 6 & 9.8 \\
\hline$\$ 50,000--54,999$ & 8 & 7.0 & 8 & 11.0 & 0 & 0.0 & 4 & 7.4 & 4 & 6.6 \\
\hline$\$ 55,000--59,999$ & 5 & 4.3 & 2 & 2.7 & 3 & 7.1 & 0 & 0.0 & 5 & 8.2 \\
\hline$\$ 60,000--64,999$ & 5 & 4.3 & 5 & 6.8 & 0 & 0.0 & 1 & 1.9 & 4 & 6.6 \\
\hline$\$ 65,000--69,999$ & 1 & 0.9 & 1 & 1.4 & 0 & 0.0 & 0 & 0.0 & 1 & 1.6 \\
\hline$\$ 70,000--74,999$ & 1 & 0.9 & 1 & 1.4 & 0 & 0.0 & 0 & 0.0 & 1 & 1.6 \\
\hline$\$ 75,000--79,999$ & 5 & 4.3 & 2 & 2.7 & 3 & 7.1 & 0 & 0.0 & 5 & 8.2 \\
\hline$\$ 80,000--84,999$ & 3 & 2.6 & 2 & 2.7 & 1 & 2.4 & 2 & 3.7 & 1 & 1.6 \\
\hline$\$ 90,000--94,999$ & 3 & 2.6 & 2 & 2.7 & 1 & 2.4 & 0 & 0.0 & 3 & 4.9 \\
\hline$\$ 100,000 \&$ above & 6 & 5.2 & 6 & 8.2 & 0 & 0.0 & 0 & 0.0 & 6 & 9.8 \\
\hline
\end{tabular}


frequently occurring current salary for respondents between the years 1997 to 2001 was under $\$ 10,000$ and the most frequently occurring salary for respondents between the years 1991 to 1996 was $\$ 35,000$ to $\$ 39,999$.

\section{$\underline{\text { Current Career Salary Based on Year Graduated }}$}

The four most frequently occurring current career salaries for the respondents that graduated between 1991 and 1996 were between $\$ 35,000$ and \$39,999 with eight $(11.1 \%)$ respondents, between $\$ 45,000$ and $\$ 49,999$ with six $(9.8 \%)$ respondents, $\$ 100,000$ and above with six $(9.8 \%)$ respondents, and between $\$ 75,000$ and $\$ 79,999$ with five $(8.2 \%)$ respondents (see Table 12). The three most frequently occurring current career salaries for the respondents that graduated between 1997 and 2001 were under \$10,000 with 14 (25.9\%) respondents, between $\$ 10,000$ and $\$ 14,999$ with seven $(13.0 \%)$ respondents, and between $\$ 25,000$ and $\$ 29,999$ with seven $(13.0 \%)$ respondents.

\section{$\underline{\text { Postgraduate Education }}$}

Graduates were asked if they had taken any graduate-level courses since receiving their baccalaureate degree and if they had completed or are enrolled in any post-graduate degrees. One hundred and six respondents $(75.7 \%)$ have taken graduate level courses (see Table 13). A total of 94 respondents $(66.2 \%)$ have earned a post-graduate degree or were enrolled in a postgraduate degree program.

Graduates were asked what type of degree they earned. The most frequently occurring post-graduate degree earned was a Doctorate degree (see Table 14) with 57 respondents (38.8\%). The second most earned post-graduate degree was Master's with 42 respondents $(28.6 \%)$. A second bachelor's degree was the third most earned post-graduate degree with 12 respondents $(8.3 \%)$ 
Table 13

Did West Virginia University's Animal and Veterinary Sciences Graduates - 1991-2001 earn a Post-Graduate Degree or take Graduate Level Courses?

Total
WVU Graduation Date

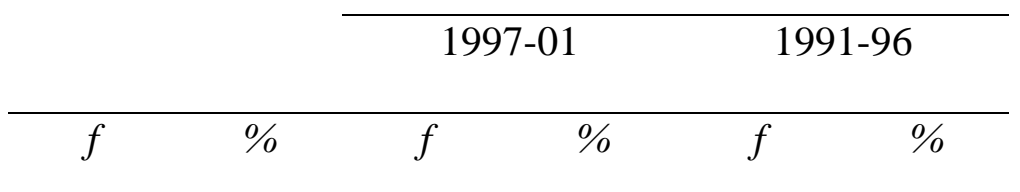

Post-Graduate Degree

Yes

94

66.2

52

65.8

42

66.7

No

48

33.8

27

$34.2 \quad 21$

Graduate-Level Courses

Yes

106

75.7

57

74.0

49

77.8

No

34

24.320

26.0

14

22.2

\section{Summary}

The population consisted of 350 university students who graduated with Bachelor of Science degrees in Animal and Veterinary Sciences from the Davis College of Agriculture and Forestry and Consumer Sciences from 1991-2001. A total of 147 surveys were returned with usable data resulting in a response rate of $63 \%$. Those who reported gender, ninety-two of the respondents (63\%) were female. For first career/occupation approximately $47 \%$ of the alumni were in one of five occupations: student in the category other, veterinary student, livestock production/management, veterinary student, and veterinarian. Respondents indicated that the 
Table 14

What type of Post-Graduate Degree did West Virginia University’s Animal and Veterinary

Sciences Graduates - 1991-2001 earn?

\begin{tabular}{|c|c|c|c|c|c|c|}
\hline & \multicolumn{2}{|c|}{ Total } & \multicolumn{4}{|c|}{ WVU Graduation Date } \\
\hline & & & \multicolumn{2}{|c|}{ 1997-01 } & \multicolumn{2}{|c|}{$1991-96$} \\
\hline & $f$ & $\%$ & $f$ & $\%$ & $f$ & $\%$ \\
\hline Post-Graduate - Bachelors & 12 & 8.2 & 3 & 4.8 & 9 & 15.8 \\
\hline Post-Graduate - Teaching & 3 & 2.0 & 2 & 3.2 & 1 & 1.7 \\
\hline Post-Graduate - Masters & 42 & 28.6 & 26 & 41.3 & 16 & 28.1 \\
\hline Post-Graduate - PhD & 3 & 2.0 & 1 & 1.6 & 2 & 3.5 \\
\hline Post-Graduate - Doctorate (e.g. DVM, MD) & 57 & 38.8 & 30 & 47.6 & 27 & 47.4 \\
\hline Post-Graduate - Other Degree & 3 & 2.0 & 1 & 1.6 & 2 & 3.5 \\
\hline
\end{tabular}

most important attributes in their first career were the ability to work with people, the ability to gain and use knowledge and verbal communication skills. For the graduates first career/occupation over half of the respondents had a starting salary of under $\$ 24,999$. The three most frequently occurring first career-starting salaries for the respondents that answered yes to a post-graduate degree were under $\$ 10,000$, between $\$ 35,000$ and $\$ 39,999$, and between $\$ 20,000$ and $\$ 24,999$. The three most frequently occurring current careers for alumni were veterinarian, student in the other category, and doctor. Over half of the respondents had a current career salary of under $\$ 39,999$. The four most frequently occurring current career salaries for the respondents that answered yes to a post-graduate degree were under $\$ 10,000$, between $\$ 10,000$ 
and $\$ 14,99$, between $\$ 45,000$ and $\$ 49,999$, and between $\$ 50,000$ and $\$ 54,000$. One hundred and six respondents $(75.7 \%)$ have taken graduate level courses. A total of 94 respondents $(66.2 \%)$ have earned a post-graduate degree. 


\section{CHAPTER V}

\section{SUMMARY, CONCLUSIONS, and RECOMMENDATIONS}

\section{Purpose of the Study}

The primary purpose of this study was to examine the career opportunities for graduates completing a Bachelor of Science degree in Animal and Veterinary Sciences at West Virginia University.

Specific Objectives

Specific objectives included: 1) to identify the type and selected factors associated with the first and current career/occupational status of recent graduates and 2) to determine if graduates were satisfied with their first and current career choice. The study also comprised of demographical data and specific attributes of importance relating to importance in the first career position.

\section{$\underline{\text { Research Questions }}$}

1. What career/occupation did graduates take upon completion of a Bachelor of Science degree in Animal and Veterinary Sciences?

2. How long did graduates stay in their first career position after completion of a Bachelor of Science degree in Animal and Veterinary Sciences?

3. Were graduates satisfied with their first career position after completion of a Bachelor of Science degree in Animal and Veterinary Sciences?

4. What was the starting salary for graduates' first career position after completion of a Bachelor of Science degree in Animal and Veterinary Sciences?

5. What attributes were important in their first career position after completion of a Bachelor of Science degree in Animal and Veterinary Sciences? 
6. What was the current career/occupation of Animal and Veterinary Sciences graduates?

7. How long had Animal and Veterinary Sciences graduates been in their current career/occupation?

8. Were Animal and Veterinary Sciences graduates satisfied with their current career position?

9. What was the current salary for Animal and Veterinary Sciences graduates?

10. Have Animal and Veterinary Sciences graduates completed any postgraduate education? $\underline{\text { Summary }}$

One hundred and forty seven Animal and Veterinary Sciences graduates from West Virginia University from the years 1991 to 2001 responded to the survey with useable data from a $63 \%$ response rate. Of those who reported more than half of the respondents were female and over half of the respondents had a post graduate degree. The most frequently occurring first and current careers of the respondents were student and veterinarian. The most important attributes in the first career position were the ability to work with people, the ability to gain and use knowledge, and verbal communication. The percent of respondents being very satisfied with their first career rose from $38.4 \%$ to $55.1 \%$ in their current career.

Conclusions

Based upon the research findings, the following conclusions were reached. The conclusions were limited to the responses from West Virginia University animal science graduates.

1. West Virginia University Animal and Veterinary Science graduates were engaged in a wide variety of careers. Respondents were placed into sixteen major career categories. 
Twenty-seven respondents were engaged in careers that did not fall within any of the sixteen categories.

2. West Virginia University Animal and Veterinary Science graduates were satisfied with both their first career selection as well as their current career. Overall, $61.6 \%$ of the respondents were satisfied with their first career. The level increased to $78 \%$ satisfaction on their current career. The level of satisfaction was $85.1 \%$ for students who pursued a post-graduate degree and 88.4\% for students who graduated between 1991 and 1996.

3. The length of time that it took graduates to enter their first career after receiving their Bachelor's degree was two months.

4. After graduating with a Bachelor of Science degree two-thirds of the graduates decided to pursue a post-graduate degree. Seventy-six percent of the respondents had completed additional course work.

5. Professional careers, doctors, veterinarian, or other medical health care careers, accounted for $36.1 \%$ of the current careers for the respondents. When you examine only those students who graduated between 1991 and 1996, the professional careers accounted for $39.7 \%$ of the respondents' current careers.

6. Respondents first (70.6\%) and current careers (79.2\%) were in their field of their choice.

7. When salaries for respondents who graduated between 1991 and 1996 were examined, the most frequent salary categories were $\$ 35,000$ - $\$ 39,999, \$ 45,000$ - $\$ 49,999$, and over $\$ 100,000$. Graduates between 1991 and 1996 best represent students who have had the opportunity to complete their post-graduate education and establish professional careers.

8. The most important attributes in a graduate's first career were the ability to work with people, ability to gain and use knowledge, and verbal communication skills. 
9. The number of respondents in the category of veterinarian doubled from the first career/occupation to the current career.

\section{$\underline{\text { Recommendations }}$}

This study was conducted to examine the career opportunities for graduates completing a Bachelor of Science degree in Animal and Veterinary Sciences at West Virginia University. Based on the review of literature and data reported in this study, the following recommendations are made:

1. Information obtained from this study should be graphically represented and used to support information presented to current students on career choices, salaries, post-graduate education, and career satisfaction of Animal and Veterinary Science graduates.

2. A companion study should be conducted to determine student satisfaction with the curriculum completed as a part of their Bachelor of Science degree in Animal and Veterinary Science.

3. This study should be replicated periodically to provide current information for Animal and Veterinary Science students.

4. Additional instructions should be provided on the career sections to avoid having respondents list "student" as either a first or current career. 


\section{REFERENCES}

American Society of Animal Science. ASAS (n.d.). What is Animal Science? Retrieved from http://www.asas.gov.

Dillman, D. A. (1978). Mail and telephone surveys. New York, NY: John Wiley and Sons.

Fleetwood, C. \& Shelley, K. (Fall 2000). The outlook for college graduates, 1998-2008: A balancing act. Occupational Outlook Quarterly, 44(3), 3-7.

Kaplin, P. S. (1991). A Child's Odyssey, $2^{\text {nd }}$ edition. St. Paul, MN: West Publishing Co.

Mau, Wei-Cheng, (2001). Job search methods, job search outcomes, and job satisfaction of college graduates: A comparison of race and sex. Journal of Employment Counseling. Vol. 38 Issue 3, p. 41, 9 p.

Meyer, J. H. (1990). Influence of alumni careers and students' educational pathways on animal science undergraduate teaching programs. Journal of Animal Science, 68, 3,056-68.

Miller, L. E. \& Smith, K. L. (1983, September/October). Handling nonresponse issues. Journal of Extension, 21, 45.

Stringer, T. T. (2000/2001, Winter). Four years after graduation: The class of 1993. Occupational Outlook Quarterly, 44(4), 16-18.

VanDalen, B. D. (1979). Understanding educational research, An introduction, (4 ${ }^{\text {th }}$ edition). New York: McGraw-Hill. 
APPENDIX A

COVER LETTER 
WEST VIRGINIA UNIVERSITY

DAVIS COLLEGE OF AGRICULTURE, FORESTRY, A N D CONSUMER SCIENCES

June 10, 2002

Dear

My undergraduate degree in Animal and Veterinary Sciences and my personal search for an occupation that utilized the knowledge and skills associated with this degree influenced my selection of this research topic. The literature lists a wide variety of careers available to individuals holding an Animal and Veterinary Sciences degree. After discussions with several colleagues about career opportunities, other than veterinary school, that utilized the knowledge and skills associated with the degree, I decided to find out how Animal and Veterinary Sciences alumni at West Virginia University utilized their degrees to enhance their career objectives.

The purpose of my thesis research is to identify the first career/occupational status of recent graduates and to identify the current career/occupational status of recent graduates. The results of the study will be used to prepare a thesis to partially fulfill the requirements for a Master of Science Degree in Agricultural and Environmental Education. By determining the satisfaction of current career choices and if there is a perceived need for additional classes, modifications can be suggested for the animal science curriculum to better meet the needs of all students.

Participation in this research study is voluntary. The questionnaire will only take a few minutes of your time. You may skip any question that you are not comfortable answering. All information will be held as confidential as possible. Questionnaire results will be reported in summary format and individual responses will not be identifiable. You will notice a code number at the top right of the first page of the questionnaire. This code will be used to identify non-respondents for follow-up and will be destroyed before data are analyzed.

A postage-paid, self-addressed return envelope is provided for your convenience. Your responses will be combined with those of other West Virginia University graduates of animal and veterinary sciences. Participation in the research by returning the questionnaire before June 20, 2002 will be greatly appreciated.

Sincerely,

Stacey M. Hawkins

Graduate Student
Harry N. Boone

Assistant Professor 
APPENDIX B

QUESTIONNAIRE 


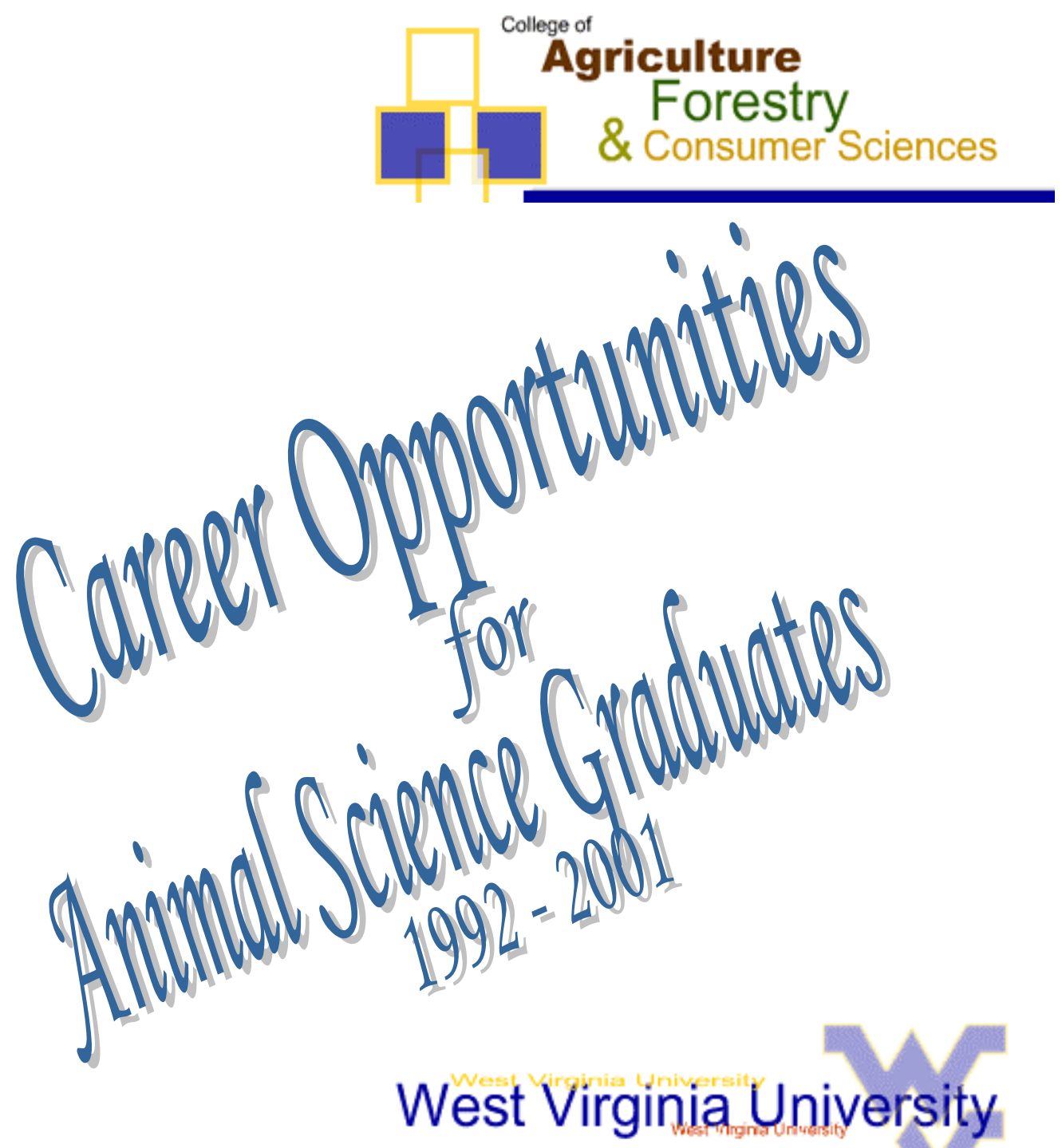




\section{Survey of Animal Science Graduates}

\section{FIRST CAREER POSITION}

1. What was your FIRST career position after completing your undergraduate education?

Job Title:

2. How many months following your graduation did it take to obtain your FIRST career position? Months

3. How many years did you hold (or have you held) your FIRST career position?

Years Months

On a scale of 1 to 4, please rate the following attributes as to their importance in your FIRST career position.

\begin{tabular}{|l|c|c|c|c|}
\hline & & & & \\
& & $\mathbf{Z}$ & & \\
\hline 4. Analytical or problem solving ability & $\mathbf{1}$ & $\mathbf{2}$ & $\mathbf{3}$ & $\mathbf{4}$ \\
\hline 5. Communication skills (Verbal) & $\mathbf{1}$ & $\mathbf{2}$ & $\mathbf{3}$ & $\mathbf{4}$ \\
\hline 6. Communication skills (Written) & $\mathbf{1}$ & $\mathbf{2}$ & $\mathbf{3}$ & $\mathbf{4}$ \\
\hline 7. Managerial ability & $\mathbf{1}$ & $\mathbf{2}$ & $\mathbf{3}$ & $\mathbf{4}$ \\
\hline 8. Leadership skills & $\mathbf{1}$ & $\mathbf{2}$ & $\mathbf{3}$ & $\mathbf{4}$ \\
\hline 9. Technical information in your field & $\mathbf{1}$ & $\mathbf{2}$ & $\mathbf{3}$ & $\mathbf{4}$ \\
\hline 10. Ability to work with people & $\mathbf{1}$ & $\mathbf{2}$ & $\mathbf{3}$ & $\mathbf{4}$ \\
\hline 11. Cross-cultural understanding of others & $\mathbf{1}$ & $\mathbf{2}$ & $\mathbf{3}$ & $\mathbf{4}$ \\
\hline 12. Concern for the environment & $\mathbf{1}$ & $\mathbf{2}$ & $\mathbf{3}$ & $\mathbf{4}$ \\
\hline 13. Ability to gain and use new information & $\mathbf{1}$ & $\mathbf{2}$ & $\mathbf{3}$ & $\mathbf{4}$ \\
\hline 14. Computer and technical skills & $\mathbf{1}$ & $\mathbf{2}$ & $\mathbf{3}$ & $\mathbf{4}$ \\
\hline
\end{tabular}


15. Was your FIRST job in the career field of your choice?

Yes — No

16. How satisfied were you with your FIRST job?

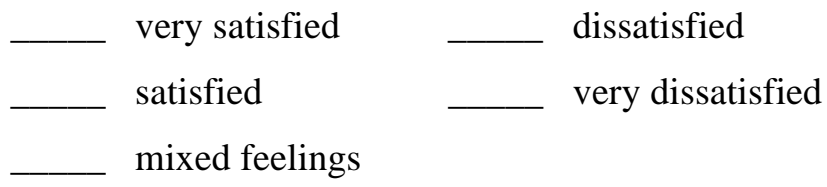

17. What was YOUR starting salary in your FIRST career position?

\begin{tabular}{|c|c|c|}
\hline Under $\$ 10,000$ & $\$ 40,000--44,999$ & $\$ 75,000--79,999$ \\
\hline \$10-000--14,999 & $\$ 45,000--49,999$ & $\$ 80,000--84,999$ \\
\hline$\$ 15,000--19,999$ & $\$ 50,000--54,999$ & $\$ 85,000--89,999$ \\
\hline$\$ 20,000--24,999$ & $\$ 55,000--59,999$ & $\$ 90,000--94,999$ \\
\hline$\$ 25,000--29,999$ & $\$ 60,000--64,999$ & $\$ 95,000--99,999$ \\
\hline$\$ 30,000--34,999$ & $\$ 65,000--69,999$ & $\$ 100,000 \&$ above \\
\hline$\$ 35,000--39,999$ & $\$ 70,000--74,999$ & \\
\hline
\end{tabular}

\section{CURRENT CAREER POSITION}

18. What is your CURRENT position?

Job Title:

19. How many years have you held your CURRENT job?

Years Months

20. How satisfied are you with your CURRENT job?

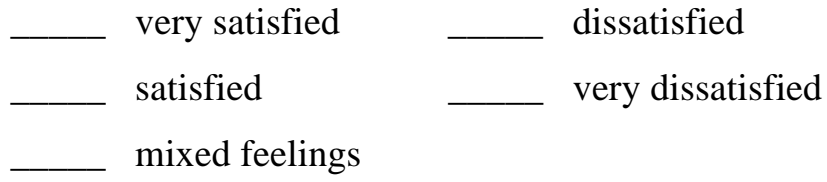

21. Is this job in the career field of your choice?

Yes No 
22. What is YOUR current salary?

\begin{tabular}{|c|c|c|}
\hline Under $\$ 10,000$ & $\$ 40,000--44,999$ & $\$ 75,000--79,999$ \\
\hline \$10-000--14,999 & $\$ 45,000--49,999$ & $\$ 80,000--84,999$ \\
\hline$\$ 15,000--19,999$ & $\$ 50,000--54,999$ & $\$ 85,000--89,999$ \\
\hline$\$ 20,000--24,999$ & $\$ 55,000--59,999$ & $\$ 90,000--94,999$ \\
\hline$\$ 25,000--29,999$ & $\$ 60,000--64,999$ & $\$ 95,000--99,999$ \\
\hline$\$ 30,000--34,999$ & $\$ 65,000--69,999$ & $\$ 100,000 \&$ above \\
\hline$\$ 35,000--39,999$ & $\$ 70,000--74,999$ & \\
\hline
\end{tabular}

\section{POSTGRADUATE EDUCATION}

23. Have you taken any graduate-level courses since receiving your baccalaureate degree?

Yes No

24. Have you completed any post-graduate degrees or are you enrolled in a program that will award you a degree?

Yes No

(Check all that apply.)

Degree Type

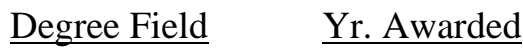

__ Second Bachelor's Degree

Teaching Credential

Master's Degree

Academic Doctorate $(\mathrm{PhD})$

Professional Doctorate

Other Degree

(Specify:

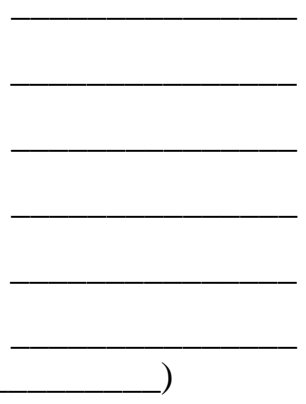

DEMOGRAPHICS

25. What year did you graduate from WVU?

26. Gender:

Male

Female

THANK YOU FOR YOUR ANSWERS AND OPINIONS.

THEY ARE GREATLY APPRECIATED 
APPENDIX C

SECOND COVER LETTER 


\section{WEST VIRGINIA UNIVERSITY \\ DAVIS COLLEGE OF AGRICULTURE, FORESTRY, A N D CONSUMER SCIENCES}

July 16, 2002

Dear,

On June 10, we sent you a questionnaire dealing with first and current careers for animal science graduates. As of today we have not received a response. I know that you are busy but your response is very important to the research efforts. Your response will be greatly appreciated.

The purpose of my thesis research is to identify the first career/occupational status of recent graduates and to identify the current career/occupational status of recent graduates. The results of the study will be used to prepare a thesis to partially fulfill the requirements for a Master of Science Degree in Agricultural and Environmental Education. By determining the satisfaction of current career choices and if there is a perceived need for additional classes, modifications can be suggested for the animal science curriculum to better meet the needs of all students.

Participation in this research study is voluntary. The questionnaire will only take a few minutes of your time. You may skip any question that you are not comfortable answering. All information will be held as confidential as possible. Questionnaire results will be reported in summary format and individual responses will not be identifiable. You will notice a code number at the top right of the first page of the questionnaire. This code will be used to identify non-respondents for follow-up and will be destroyed before data are analyzed.

A postage-paid, self-addressed return envelope is provided for your convenience. Your responses will be combined with those of other West Virginia University graduates of animal and veterinary sciences. Participation in the research by returning the questionnaire before July 26, 2002 will be greatly appreciated.

Sincerely,

Stacey M. Hawkins

Graduate Student
Harry N. Boone

Assistant Professor 
APPENDIX D

CONTINGENCY TABLE 
Table 17

Current Career by Current Salary

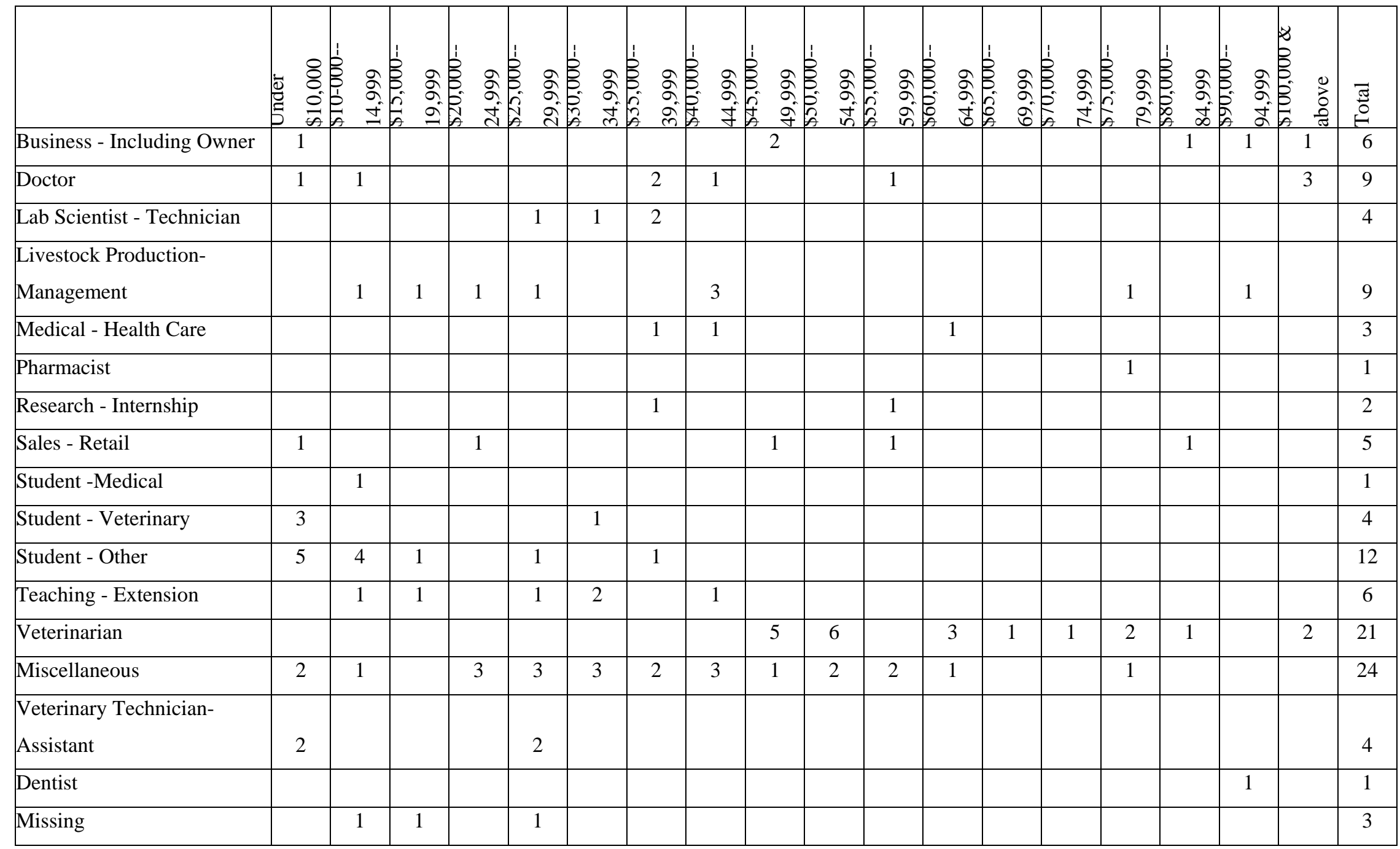


VITA 


\section{Stacey M. H ankins \\ 3034 Skyline Terrace $\downarrow$ Fairmont, WV 26554 \\ Home Phone 363-8568 Email shawkin3@wvu.edu}

\begin{tabular}{lllllllll}
$\mathbf{E}$ & $\mathbf{D}$ & $\mathbf{U}$ & $\mathbf{C}$ & $\mathbf{A}$ & $\mathbf{T}$ & $\mathbf{I}$ & $\mathbf{O}$ & $\mathbf{N}$ \\
\hline
\end{tabular}

West Virginia University, Morgantown, WV 26506.

Pursuing a Master of Science in Agricultural and Environmental Education.

Course work specializing in: agricultural education and cooperative extension.

Date of graduation, December 2002.

West Virginia University, Morgantown, WV 26506.

Bachelor of Science in Agriculture with a major of Animal and Veterinary

Science. Course work specializing in:animal science, biology, animal

nutrition, production and physiology, genetics and agriculture economics.

\begin{tabular}{llllllllllllllllllllllll}
$\mathbf{P}$ & $\mathbf{R}$ & $\mathbf{O}$ & $\mathbf{F}$ & $\mathbf{E}$ & $\mathbf{S}$ & $\mathbf{S}$ & $\mathbf{I}$ & $\mathbf{O}$ & $\mathbf{N}$ & $\mathbf{A}$ & $\mathbf{L}$ & $\mathbf{E}$ & $\mathbf{X}$ & $\mathbf{P}$ & $\mathbf{E}$ & $\mathbf{R}$ & $\mathbf{I}$ & $\mathbf{E}$ & $\mathbf{N}$ & $\mathbf{C}$ & $\mathbf{E}$ \\
\hline
\end{tabular}

Veterinary Technician, Mountaineer Veterinary Clinic,

Morgantown, WV 26505.

Responsibilities included: Filling prescriptions, scheduling appointments, preparing and reading slides, preparing vaccines, assisting in surgeries and animal caretaking.

\begin{tabular}{lllllllllllllll}
$\mathbf{W}$ & $\mathbf{O}$ & $\mathbf{R}$ & $\mathbf{K}$ & & $\mathbf{E}$ & $\mathbf{X}$ & $\mathbf{P}$ & $\mathbf{E}$ & $\mathbf{R}$ & $\mathbf{I}$ & $\mathbf{E}$ & $\mathbf{N}$ & $\mathbf{C}$ & $\mathbf{E}$ \\
\hline
\end{tabular}

Par 4 Server, Cracker Barrel, Fairmont, WV 26554.

Responsibilities included: Taking orders, serving, preparing food, product knowledge and cleanliness of designated areas.

Waitress, Westchester Village and Bistro, Fairmont, WV 26554.

Responsibilities included: Taking orders, serving, decorating and preparing rooms for banquets, preparing food and cleanliness of designated areas.

\begin{tabular}{lllllllllllllllll}
$\mathbf{I}$ & $\mathbf{N}$ & $\mathbf{V}$ & $\mathbf{I}$ & $\mathbf{T}$ & $\mathbf{E}$ & $\mathbf{D}$ & & $\mathbf{H}$ & $\mathbf{O}$ & $\mathbf{N}$ & $\mathbf{O}$ & $\mathbf{R}$ & $\mathbf{A}$ & $\mathbf{R}$ & $\mathbf{Y}$ \\
\hline
\end{tabular}

Sigma Alpha - Historian 